\title{
Strategi Keamanan Maritim Indonesia terhadap Maritime Piracy di Laut Sulu Tahun 2016
}

\author{
Ayu Laksmi Saraswati ${ }^{1}$, Ni Komang Desy Setiawati Arya Pinatib ${ }^{2}$ \\ Universitas Brawijaya
}

\begin{abstract}
The Sulu Sea, one of Indonesia's seas located in the strategic area of ALKI II (Indonesian Archipelagic Sea Lane), directly borders Malaysia and the Philippines. As a busy trade route, the sea is also vulnerable to threats such as maritime piracy. This research aims to see Indonesia's maritime security strategy in the Sulu Sea over maritime piracy cases in the area during 2016. In this research, the writer uses the Maritime Security concept proposed by Chris Rahman to explain Indonesia's maritime security strategy in the Sulu Sea. The author using three variables, including (1) security of the sea itself: conservation and protection; (2) ocean governance; (3) maritime border protection; (4) military activities at sea, and (5) security regulation of the transport marine system in their correlation with each other. The author then concludes that out of five variables, only two are suitable and effective for implementing piracies in the Sulu Sea, namely maritime border protection and military activities at sea.
\end{abstract}

Keywords: Indonesia, Sulu sea, maritime security, maritime piracy

\section{PENDAHULUAN}

Laut merupakan penghubung utama antar negara-negara di dunia, walaupun beberapa negara berada pada kawasan landlocked, hal tersebut tidak menutup kemungkinan kebutuhan negara atas laut. Fenomena tersebut disebabkan karena sekitar 90 persen dari seluruh aktivitas lintas batas negara sebagian besar dijalankan menggunakan jalur laut (Conway 2008). Indonesia, dan sebagian besar negara-negara Asia Tenggara yang wilayahnya merupakan perairan memiliki masalah keamanan terkait jalur laut. Salah satu wilayah perairan Indonesia yang memiliki nilai strategis adalah Laut Sulu, dimana laut ini adalah trek pelayaran yang paling padat juga berbahaya setelah Selat Malaka. Rata-rata setiap tahun ada sekitar 3900 kapal yang melalui trek ini dengan nilai barang mencapai US $\$ 40$ miliar (Prastyono 2005). Banyak negara menggunakan laut ini untuk kepentingannya dalam berdagang karena potensi, letak dan kuantitas kegiatan lautnya yang padat. Namun hal tersebut juga menjadi faktor berbagai ancaman yang terjadi seperti masalah pelanggaran wilayah karena posisi yang tepat berbatasan dengan tiga negara (Indonesia, Malaysia dan Filipina), masalah penyelundupan senjata, perdagangan manusia, penangkapan ikan secara ilegal hingga pembajakan (piracy)(Gumilang 2016).

Indonesia yang merupakan negara kepulauan atau archipelagic state mengharuskan negara untuk menjaga keutuhan dan kesatuan wilayah nasional yang mencangkup darat, laut maupun udara. Dalam hubungannya dengan hal tersebut Undang-Undang No. 6 tahun 1996 dan PP No. 37 tahun 2002 kemudian menerangkan bahwa Alur Laut Kepulauan yaitu alur laut yang dilewati oleh kapal atau pesawat udara asing di atas alur laut tersebut yang digunakan untuk melakukan pelayaran dan penerbangan dengan cara normal secara belaka untuk transit yang berulang-ulang, langsung dan secepat mungkin serta tidak terhalang melewati atau di atas perairan kepulauan dan laut teritorial yang berdampingan antara satu bagian laut lepas atau Zona Ekonomi Eksklusif (ZEE) Indonesia dan yang lainnya (BPK RI 1996). 
Indonesia dalam hal ini memiliki tiga jalur Alur Laut Kepulauan Indonesia (ALKI) International Maritim Organization (Peraturan Pemerintah RI 2002) serta lima daerah choke points antara lain Selat Singapura, Selat Malaka, Selat Lombok, Selat Ombai-Wetar, dan Selat Sunda (Kemenko Kemaritiman 2017). Dalam hal ini Laut Sulu berhubungan langsung dengan Laut Sulawesi yang merupakan perairan yang membentuk pintu masuk ke daerah ALKI II yang terhubung ke Selat Makassar, Laut Flores dan Selat Lombok menuju Samudera Hindia. Alur ALKI II membentuk pintu alternatif kedua setelah Selat Malaka untuk negara melaksanakan kepentingannya di lautan, termasuk melakukan perdagangan karena jalurnya yang strategis untuk pelayaran kapal angkut menuju Asia Timur dan sebaliknya. Jalur ini juga sering digunakan bagi kapal-kapal tanker besar yang memiliki bobot lebih dari 200.000 ton dengan berbagai muatan. Laut Sulawesi dalam hal ini berbatasan langsung dengan Samudera Pasifik, Laut Sulu dan pulau-pulau di Filipina Selatan serta perairan ini merupakan perairan yang banyak akan terumbu karang dan biota laut sehingga mempunyai nilai ekonomis yang tinggi (Rustam 2017).

Laut Sulu-Sulawesi mempunyai nilai strategis karena ribuan armada tanker minyak dan armada dagang melewati Laut Sulu-Sulawesi karena potensi, letak maupun kuantitas kegiatan laut yang padat pada trek tersebut. Selain itu karena letaknya di puncak Segitiga Terumbu Karang Dunia yang mengiris tiga negara yaitu Indonesia, Filipina dan Malaysia, hal tersebut menambah nilai yang dimiliki perairan ini (Rustam 2017). Namun keuntungan tersebut bukan cuma menimbulkan pengaruh baik, melainkan menyebabkan berbagai ancaman juga di lautan seperti diantaranya pelanggaran wilayah karena posisinya yang berbatasan dengan tiga negara, konflik penangkapan ikan secara ilegal, penerobosan senjata dan human trafficking, hingga masalah perampokan kapal dan penculikan awak kapal (maritime piracy).

Pembajakan (piracy) dianggap sebagai suatu ancaman yang kritis dalam keamanan maritime pada wilayah Asia Tenggara. Semakin berlalunya waktu, banyaknya kejadian piracy yang terjadi di kawasan dalam beberapa tahun terakhir, ancaman ini kemudian mendapat banyak perhatian dari International Maritime Organisation (IMO) dan the International Maritime Bureau (IMB) yang berfokus pada isu piracy. IMO merupakan organisasi yang dinaungi oleh PBB dimana dalam mendefinisikan pembajakan mengadopsi pengertian dan definisi yang telah dijelaskan oleh United Nations Convention on the Law of the Sea (UNCLOS) (Johnson, Derek; Valencia 2005). Secara singkat piracy diartikan sebagai suatu tindakan memasuki kapal dengan tujuan untuk melakukan pencurian ataupun tindakan jahat lainnya dengan maksud tertentu melalui adanya kekerasan dalam melakukan aktivitas pembajakan kapal tersebut. Definisi yang dimaksud juga cukup dekat dalam mengidentifikasi beberapa aktivitas ilegal yang dilakukan di laut dan dilihat berpotensi sebagai suatu pembajakan atau piracy. Sementara disisi lain, IMB yang merupakan bagian dalam International Chamber of Commerce (ICC) yang diperkirakan memiliki kesamaan agenda, yang mencakup segala sesuatu atau aktivitas pembajakan dan perlawanan pada kapal dalam yurisdiksi maritime suatu negara.

Aktivitas pembajakan di laut (maritime piracy) di kawasan Asia Tenggara secara umum dilaporkan meningkat dalam beberapa dekade terakhir, fenomena ini dapat dilihat dengan adanya perubahan jumlah secara drastis sejak akhir 1990 an hingga pada awal 2000an, dimana 94 insiden pada tahun 1998 berkembang menjadi 257 pada tahun 2000 dan 187 di tahun 2003 (ICC IMB 2017). Hal ini tidak terlepas dari pengaruh aksi teroris $9 / 11$ dalam dunia internasional. Kemunculan pembajakan dan perampokan di laut juga tidak terlepas dari beberapa faktor seperti kondisi sosial ekonomi yang lemah, lemahnya pengawasan pemerintah dan kapasitas negara serta hal ini juga disebabkan oleh semakin berkembangnya 
teknologi baru untuk mempermudah melakukan aksi kriminal di lautan (maritime criminal) seperti navigasi satelit, ponsel maupun internet (Storey 2016).

Maritime piracy yang terjadi di wilayah perairan Indonesia banyak terjadi di beberapa area antara lain Selat Malaka, Selat antara Singapura dan Filipina, termasuk Provinsi Riau di Indonesia, Teluk Thailand, Laut China Selatan hingga Laut Sulu yang berbatasan langsung dengan Malaysia, Filipina Selatan dan Indonesia (Storey 2016). Hal ini memberikan ancaman serius pada kehidupan manusia, perdagangan kapal secara internasional maupun industri maritim lokal yang mencakup penangkapan ikan serta perdagangan lokal. Dalam kawasan seperti Asia Tenggara yang mengedepankan keamanan maritime sebagai suatu fokus keamanan yang cukup signifikan, ancaman dalam kawasan maritime kemudian menjadi perhatian bersama sebagai suatu transnational security issue yang membutuhkan perhatian baik secara multilateral maupun internasional (Storey 2016).

Pembajakan dan perampokan terhadap kapal seperti yang ditulis Oceans Beyond Piracy (OBP) pada tahun 2016 telah terjadi 129 insiden baik pembajakan maupun perampokan di Asia diantaranya pembajakan dan pencurian kapal kargo, perampokan bersenjata, kesalahan pada pengangkutan dan penyerangan, penculikan hingga aktivitas mencurigakan lainnya (OBP 2017). Secara umum pada tahun 2016 terjadi pengurangan jumlah hingga 35\% kasus yang terjadi di Asia. Penurunan jumlah insiden terutama di area yang rawan kejahatan dapat dikaitkan dengan suksesnya patrol terkoordinasi dan pengawasan lebih efektif yang dilakukan oleh negara-negara pesisir, mekanisme pembagian informasi yang digunakan oleh badan informasi regional, serta kerjasama antara pemerintah daerah, organisasi mitra maupun komunitas kapal itu sendiri (Regional Cooperation Agreement on Combating Piracy and Armed Robbery against Ships in Asia Information Sharing Center (ReCAAP) 2017). Kendati demikian pada 2016 penculikan yang dilakukan semakin meningkat khususnya di Laut Sulu dan Laut Sulawesi. Dalam aktivitas ini para pelaku seringkali memindahkan sandera ke pantai dimana mereka ditahan dalam jangka waktu yang lama di bawah paksaan yang ekstrim. Tawanan juga seringkali menjadi korban pelecehan dan hidup dalam ketakutan akan dibunuh oleh para pelaku penculikan. Laporan lain juga menjelaskan bahwa sandera juga sering dimanfaatkan sebagai buruh kasar (Malaysia Kini 2017).

OBP dalam laporannya menyampaikan bahwa pada tahun 2016 ada sekitar 38 insiden yang terjadi di sekitar Laut Sulu, dimana 21 kasus diantaranya merupakan kasus penculikan, 4 kasus perampokan bersenjata, 4 kasus kegagalan dalam pengangkutan dan penyerangan (failed boarding/failed attack), 1 kasus perampokan serta 8 insiden lainnya diklasifikasikan sebagai aktivitas mencurigakan. Aktivitas yang dilakukan oleh pembajak kapal di Laut Sulu pada mulanya menargetkan kapal-kapal kecil pada awal tahun, hingga pada Oktober mereka mulai menargetkan dan menyerang kapal yang lebih besar dan menghadirkan ancaman terhadap lalu lintas perdagangan melalui jalur laut, baik secara internasional maupun regional (ReCAAP 2017; Stable Seas 2019).

Indonesia adalah salah satu dari negara kepulauan terluas dengan area perairan dan panjang garis pantai yang luas menimbulkan limitasi kapasitas TNI (Tentara Nasional Indonesia) dan Polri (Kepolisian Republik Indonesia) untuk menjaga dan menjamin pertahanan dan keamanan di setiap daerah dari berbagai macam ancaman. Kesempatan tersebut kemudian dimanfaatkan para pelaku kejahatan transnasional untuk melaksanakan aksinya, termasuk maritime piracy yang seringkali dilakukan kelompok radikal Abu Sayyaf yang diidentikkan dengan terorisme pada sejumlah warga negara Indonesia. Laut Sulu dalam hal ini merupakan rute kapal tongkang dari Indonesia ke Filipina Selatan, yang biasanya bermuatan batubara maupun minyak (BBC Indonesia 2017). Interaksi tersebut kemudian memberikan kesempatan pada komunitas Abu Sayyaf ini melakukan tindakan pembajakan 
kapal dan penculikan di wilayah perairan Filipina. Dalam laporan ReCAAP (The Regional Cooperation Agreement on Combating Piracy and Armed Robbery against Ships in Asia) sepanjang tahun 2016 telah terdapat 16 kali insiden penculikan kru kapal di Laut Sulawesi dan Laut Sulu (ReCAAP 2016).

Beberapa kasus pembajakan dan penculikan (maritime piracy) WNI yang dilakukan oleh kelompok Abu Sayyaf banyak terjadi sejak tahun 2002 dimana saat itu kapal Lebroy 179 yang berlayar dari Indonesia hingga Kota Cebu yang kemudian terdapat 4 anak buah kapal (ABK) dibajak. Kemudian Desember 2004, 9 orang WNI yang merupakan awak kapal tunda Christian disandra di Laut Sulu (Partogi 2016). Kemudian di bulan Maret 2016 dimana dua kapal kargo Indonesia yaitu tunda Brahma 12 dan kapal tongkang Anand 12 beserta $10 \mathrm{kru}$ awak kapal yang memuat 7.000 ton batubara dibajak di perairan perbatasan Filipina dan Indonesia (BBC Indonesia 2016). Pada 15 April 2016, 4 awak kapal tunda Henry dan tongkang Christy juga ditangkap dan diculik saat berlayar dari Cebu ke Tarakan. Kasus-kasus penculikan dan pembajakan oleh Kelompok abu Sayyaf terus berlanjut terjadi sepanjang tahun 2016. Selain mencuri muatan kapal, tujuan lain kelompok Abu Sayyaf ini adalah untuk meminta uang tebusan kepada negara asal korban yang diculik (Partogi 2016; ReCAAP 2016).

Melihat banyaknya aksi maritime piracy yang dilakukan oleh kelompok Abu Sayyaf terhadap WNI dalam jangka waktu yang relatif singkat dan berkala tersebut kemudian mendorong penulis untuk menganalisis mengenai strategi keamanan maritim wilayah perbatasan Indonesia dalam menangani aksi kejahatan transnasional, dimana dalam hal ini maritime piracy yang kerap terjadi di Laut Sulu. Dengan demikian, penulis akan mengkaji bagaimana strategi keamanan maritim Indonesia dalam menanggulangi perkembangan maritime piracy di Laut sulu pada tahun 2016 yang sekaligus menjadi rumusan permasalahan dalam jurnal ini.

Dalam hal ini penulis melihat bahwa kelima faktor yaitu security of the sea itself, ocean governance, maritime border protection, military activities at sea serta security regulation of the marine transportation dapat dijadikan acuan untuk melihat seberapa besar upaya yang telah dilakukan Indonesia dalam memproteksi wilayah perbatasan dan menanggulangi ancaman maritime piracy yang terjadi di Laut Sulu. Maka strategi keamanan maritime yang telah dilaksanakan oleh Indonesia dapat dilihat melalui setiap variabel yang disebutkan oleh Chris Rahman, baik variabel yang bersifat non tradisional maupun tradisional. Namun dalam hal ini penulis melihat bahwa peningkatan keamanan maritim melalui variabel maritime border protection serta military activities at sea melalui latihan gabungan, pengadaan joint operation maupun maritime patrol antar negara yang berbatasan langsung dengan Laut Sulu (misalnya seperti Malaysia dan Filipina) merupakan strategi yang efektif dalam mencapai keamanan maritim yang stabil di Indonesia.

\section{KERANGKA PEMIKIRAN}

Penulis menemukan bahwa konsep keamanan maritim (maritime security) juga pernah digunakan untuk meneliti berbagai ancaman kejahatan non traditional, khususnya kejahatan yang dilakukan di wilayah perairan (lautan). Seperti pada tesis yang ditulis oleh Richarunia Wenny Ikhtiari yang merupakan Alumni Program Pascasarjana Universitas Indonesia yang berjudul "Strategi Keamanan Maritim Indonesia dalam Menanggulangi Ancaman NonTraditional Security, Studi Kasus: Illegal Fishing periode tahun 2005-2010 (Wenny Ikhtiari 2011). Dalam tesis tersebut penulis melihat terdapat kesamaan pendekatan dalam melihat kasus kejahatan yang terjadi di wilayah perairan yakni menggunakan konsep maritime security. Dalam tesis ini dijelaskan bahwa maritime security merupakan perluasan dari perdebatan mengenai konsep keamanan secara umum, namun dalam hakikatnya maritime security tidak dipersepsikan sebagai isu yang tidak terikat pada sektor tertentu melainkan bisa menimbulkan beberapa 
masalah pada sektor-sektor interaksi antar aktor baik aktor negara ataupun bukan negara. Maritime security juga dijelaskan cenderung mendalami ciri laut dan penggunaannya serta ancaman yang dihadapi (Rahman 2009). Lebih lanjut maritime security kemudian juga digunakan untuk menjawab mengenai strategi keamanan laut dalam mengatasi isu illegal fishing, dimana dalam tesisnya penulis melihat bahwa terdapat berbagai kelemahan Indonesia dalam melaksanakan keamanan laut, hingga perlu dilakukan peningkatan terhadap komponen pengawasan dan pengelolaan kelautan yang dirasa masih terdapat kekurangan untuk menghasilkan suatu keadaan yang stabil bukan cuma di Indonesia, tapi juga di kawasan.

Dalam kerangka teori yang digunakan pada tesis ini penulis berupaya menerangkan mengenai maritime security yang dipandang dari segi militer serta hukum internasional. Setelah diteliti lebih lanjut, penulis melihat bahwa persamaan antara penelitian yang hendak dilakukan oleh penulis dengan tesis tersebut terletak pada konsep maritime security yang dipakai, dimana dalam hal ini penulis lebih menyorot dari aspek peranan militer. Militer dalam hal ini khususnya angkatan laut memiliki peranan penting dalam upaya melaksanakan pertahanan laut dari ancaman illegal fishing, yang sebenarnya bukanlah ancaman berdimensi penyerangan militer, melainkan pada skalanya merupakan penyerangan kedaulatan yang dilakukan oleh aktor non negara (Wenny Ikhtiari 2011).

\section{Definisi Keamanan Maritim (Maritime Security)}

Istilah maritime security atau keamanan maritim pada mulanya berawal dari ekspansi makna dan scope dari konsep keamanan setelah perang dingin. Secara tradisional masalah keamanan umumnya ditafsirkan dengan adanya suatu bahaya yang datang dari negara lain yang erat kaitannya dengan ancaman militer. Namun dalam perkembangannya semakin kompleks interaksi antar aktor baik negara ataupun aktor selain negara menjadikan ancaman tidak hanya dipersepsikan secara konvensional (tradisional) saja, melainkan berkembang pula ancaman non tradisional. Hal ini kemudian memunculkan perluasan dan transisi pemahaman keamanan menuju keamanan non militer (Winarno 2008).

Keamanan maritim (maritime security) dalam pendekatan tradisional merujuk pada strategi angkatan laut dalam aspek menjaga dan mengamankan batas-batas nasional maritim (national maritime borders) dan area sensitif di lautan yang digunakan sebagai jalur perdagangan (sensitive maritime trade choke-points) (Mudric 2016). Dalam memetakan konsep baru dalam maritime security, Christian Buerger menjelaskan bahwa konsep keamanan maritim didasarkan pada kerangka konvergen yang harus mematuhi konsep-konsep tradisional dan dalam saat yang bersamaan harus dapat mengidentifikasi kesamaan yang akan memungkinkan penggabungan bertahap pada isu-isu yang lebih luas (Mudric 2016). Kemudian dalam hal ini Buerger mengidentifikasi tiga kerangka kerja dalam memahami maritime security lebih lanjut yakni (1) the matrix framework, yang menggabungkan the concept of marine safety, sea- power, blue economy and resilience; (2) the securitization framework, yang membahas mengenai interrelasi (interrelationship) antara ancaman maritime dan perbedaan kepentingan politik serta ideology; (3) the security practice theory, membahas mengenai intensi sebenarnya (true intention) dan aksi pada aktor-aktor-aktor yang terlibat dalam arena keamanan maritime (Mudric 2016).

Buerger melalui pendekatan the matrix framework kemudian menjelaskan Maritime security memiliki hubungan terhadap empat konsep yakni national security, marine environment, economic development serta buman security yang kemudian secara grafis digambarkan dengan matriks berikut (Buerger 2015). 
Gambar 1. Maritime security matrix

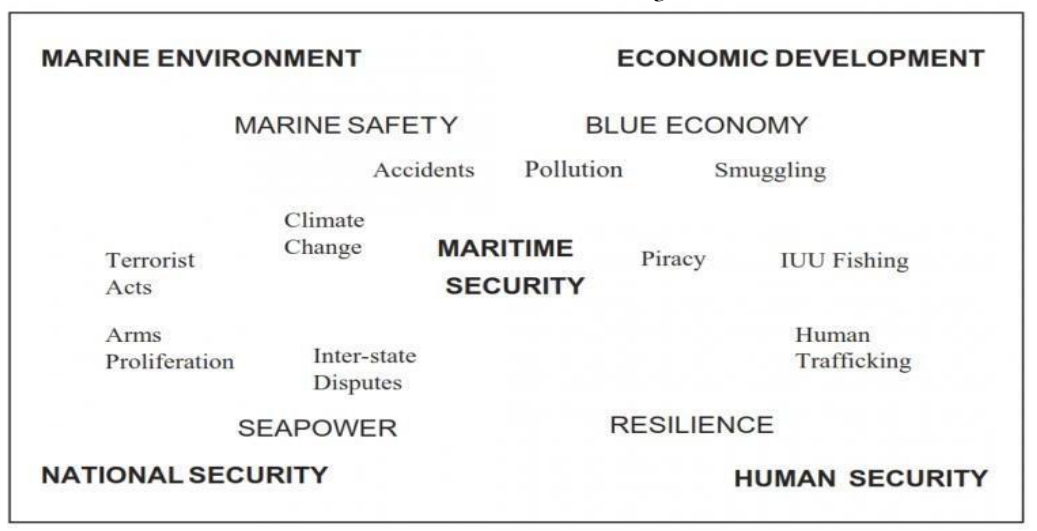

Sumber: (Buerger 2015)

Dalam konteks keamanan nasional (national security) keamanan maritim seringkali berhubungan dengan perang di lautan (naval warfare), pentingnya power projection serta konsep sea power dalam rangka melindungi dan mempertahankan eksistensi dan kedaulatan suatu negara. Sementara marine environment menyorot mengenai instalasi maritim dan keamanan dari kapal dengan tujuan untuk melindungi keseluruhan lingkungan maritime (maritime environment) dan para profesional dalam bidang maritime (maritime professional). Maritime security juga mencakup isu perkembangan ekonomi. Sebagaimana lautan memiliki peranan yang penting dalam perkembangan ekonomi global dari waktu ke waktu, mengingat mayoritas perdagangan yang dilakukan tidak terlepas dari aktivitas di lautan. Selain itu, industri perkapalan global juga merupakan industri yang sangat menjanjikan dalam menaikkan nilai komersial daripada lautan (Bagus 2016; Buerger 2015).

\section{Konsep Keamanan Maritim}

Konsep keamanan maritim (maritime security) menurut Chris Rahman memiliki pengertian yang berbeda tergantung individu atau organisasi yang mendefinisikan, termasuk didalamnya tergantung kepentingan dalam organisasi, atau bias politik maupun ideologi. Secara khusus terminology ini kemudian dimanfaatkan dalam cara yang kurang maju dan serampangan (underdeveloped way dan carefree). Keamanan maritim secara sederhana seringkali dilihat sebagai dimensi lain atau sisi lain dari keamanan, walaupun beberapa kajian literatur mengenai keamanan secara mengejutkan menjelaskan bahwa keamanan maritim tidak pernah diidentifikasi sebagai sektor isu yang berdiri sendiri melainkan tetap menjadi bagian dari isu keamanan (Rahman 2009). Namun kebanyakan literatur mengenai keamanan maritim saat ini menjelaskan bahwa keamanan maritim cenderung berfokus pada karakteristik laut dan berbagai kegunaannya, serta ancaman yang mungkin ditimbulkan dari kegunaan laut tersebut (Rahman 2009).

Chris Rahman menjelaskan maritime security melalui beberapa pendekatan yang melihat keamanan maritim dari perspektif non tradisional (non strategis). Perspektif yang digunakan dalam pendekatan ini tak jarang tumpang tindih, karena saling berkaitan dan untuk beberapa kasus merepresentasikan aspek yang berbeda dari permasalahan yang sama untuk mengetahui manakaj pendekatan yang lebih efektif dalam mengelola kelautan serta mempertahankan good order diantaranya. Kebijakan praktis dan respon operasional oleh negara pada keamanan maritim mereka biasanya membutuhkan aspek-aspek yang menggabungkan lebih dari satu pendekatan ini. Pendekatan yang ditawarkan oleh Chris Rahman dalam melihat hal tersebut adalah dengan melihat: (1) Security of the sea itself; (2) ocean governance; (3) maritime border protection; (4) military activities at sea; serta (5) security regulation of the maritime transportation system (Rahman 2009). 


\section{1) Proteksi terhadap Ekosistem Laut}

Keamanan di lautan, merupakan kategori pertama dari keamanan maritime dimana dalam hal ini harus dapat merefleksikan kepercayaan environmentalist yang melihat bahwa lautan sebagai suatu objek keamanan daripada politik kelautan (maritime politics) dan oleh karenanya perlu untuk diamankan demi kebaikan bersama. Proteksi yang dimaksud kemudian mencakup proteksi dan keamanan lingkungan kelautan (protection of the marine environment) serta konservasi terhadap segala sumber daya yang ada di lautan (baik yang hidup atau living maupun non- living) sebagai garis terdepan dari konsep keamanan maritime.

Pendekatan ini dikemukakan oleh 1987 WCED report dalam chapter 17 of agenda 21 yang menjelaskan mengenai keamanan di lautan, yang kemudian diadopsi pada 1992 oleh UN Conference on Environment and Development. Hal ini kemudian diaplikasikan bahkan dalam US National Strategy for Maritime Security, yang melaksanakan counterterrorism dalam domain maritim sebagai salah satu objek strategis dalam pelaksanaan proteksi dan keamanan serta upaya menanggulangi eksploitasi ilegal terhadap sumber daya. Pada hakikatnya penting untuk menjaga kelestarian dan keamanan laut mengingat dampaknya pada buman existence, perkembangan dan keamanan, maka pendekatan ini kemudian melihat pada karakteristik spesial yang dimiliki oleh laut, serta menuntut adanya "freedom for the seas" termasuk dalam lingkungan kelautan (maritime environment) serta ekosistem yang ada didalamnya (Rahman 2009).

\section{2) Tata Kelola Maritim}

Dalam menjelaskan tata kelola kelautan (ocean governance) menurut Chris Rahman juga memiliki bias kuat pada lingkungan kemaritiman. Ocean governance dideskripsikan sebagai suatu kreasi dan implementasi daripada aturan-aturan serta praktek untuk mengelola pengguna serta penggunaan laut (Rahman 2009). Tidak adanya pengaturan mengenai world government dalam tata kelola kelautan maka penting membuat suatu rezim yang berisi aturan serta dapat ditaati oleh negara-negara terkait penggunaan laut. Hal ini dimaksudkan untuk menyediakan wadah untuk menyelesaikan konflik yang mungkin terjadi karena penyalahgunaan manfaat kelautan.

Walaupun sebenarnya telah ada Hukum Konvensi Laut sebagai pendekatan dalam tata kelola laut, pengaturan terhadap laut perlu untuk diimplementasikan secara nyata. Konvensi tersebut dalam hal ini menyediakan berbagai sarana untuk menyeimbangkan hal tersebut, namun global ocean governance secara konstan mempengaruhi sistem sehingga perlu ada pembaharuan nyata yang diwadahi dengan suatu yurisdiksi hukum yang perlu ditaati bersama. Ocean governance dalam hal ini dapat berupa organisasi internasional, pemerintahan, institusi maupun organisasi non pemerintah (Rahman 2009).

Global governance dimaksudkan sebagai industri pertumbuhan global dalam organisasi internasional, pemerintahan, institusi maupun organisasi non pemerintah. Maka dalam hal ini global governance sebagai pendekatan ocean management dalam keamanan maritim berfungsi untuk mempromosikan, memperkuat pertahanan baik secara politik maupun retorikal dan institusional dalam sebuah sistem demi mencapai suatu rezim maritim yang stabil (apabila ada) (Rahman 2009). Kendati demikian rezim maritim yang stabil dalam pengelolaan tata kelola laut yang efektif pun belum tentu dapat memberikan keamanan, melainkan sebagai media untuk menyusun framework yang dibutuhkan dalam rangka mewujudkan keamanan dalam laut dalam kaitannya dengan hubungan internasional. 


\section{3) Perlindungan Perbatasan Laut}

Untuk mencapai tata kelola kelautan yang efektif, diperlukan upaya penjagaan dan pengamanan terhadap yurisdiksi maritime negara perlu untuk diperketat. Menjaga kedaulatan negara di lautan merupakan konsep keamanan nasional dari setiap negara. Dalam hal ini setiap negara patut untuk menaati yurisdiksi dan batasbatas wilayah yang telah ditetapkan oleh the Law of the Sea Convention, serta tak terkecuali rezim ZEE (Zona Ekonomi Eksklusif) yang mengatakan bahwa yurisdiksi kelautan suatu dapat dihitung sepanjang ZEE negara tersebut dengan maksimal 200 mil dari garis dasar pantai (Rahman 2009). Sehingga melalui yurisdiksi tersebut negara dapat memiliki kedaulatan penuh akan apa yang ada dalam wilayah lautnya, termasuk pengelolaan segala sumber daya yang ada didalamnya. Dampak dari hal tersebut adalah tak jarang terjadi pelanggaran terhadap hal tersebut karena tingginya pertumbuhan permintaan offshore oil maupun gas project yang ada di lautan di seluruh dunia. Oleh karenanya perketatan proteksi di lautan khususnya di batas wilayah (border) perlu ditingkatkan untuk menanggulangi kejahatan transnasional seperti piracy, terorisme, pencurian, penyelundupan illegal, dsb.

Pendekatan ini kemudian melihat bahwa apabila suatu negara ingin mengembangkan dan memaksimalkan proteksi di wilayah perbatasan lautan negara tersebut maka perlu adanya koordinasi yang lebih dekat dengan negara lain, atau actor/agensi lain yang bersangkutan dengan mengembangkan strategi dan kebijakannya baik dalam level nasional (national strategy for maritime security) maupun di level internasional. Mengingat adanya physically borderless serta fungsi laut sebagai jalur perdagangan, tidak jarang ancaman transnasional akan muncul dari sana. Maka secara prinsipnya pendekatan ini dapat dilihat sebagai upaya untuk menjaga kedaulatan dan kepentingan maritime suatu negara dalam zona kelautannya.

\section{4) Aktivitas Militer di Lautan}

Pendekatan aktivitas militer di lautan melihat keamanan secara tradisional seperti dalam konsep common security. Termasuk penekanan terhadap penggunaan senjata (arms control), khususnya dalam operasi- operasi yang beragam. Aktivitas militer di lautan umumnya didominasi oleh aktivitas yang dilakukan angkatan laut, namun dalam pelaksanaanya tidak selalu naval arms control tidak selalu berjalan mulus. Hal ini didasarkan oleh beberapa faktor seperti: (1) mahalnya persenjataan angkatan laut dan biasanya tersedia dalam jumlah terbatas; (2) physically borderless nature di lautan mobilitas yang inheren menyebabkan naval arms control tidak dapat dibatasi secara berarti; (3) adanya asimetris yang besar antara naval force structures serta postur strategis nasional; (4) kombatan di permukaan harus memiliki inherently flexible platform agar dapat melakukan berbagai macam perdan selain berperang, misalnya diplomatic serta melakukan riset; (5) adanya permintaan mengenai naval platform yang lebih besar dari sebelumnya termasuk border protection dan ocean governance; (6) adanya pergeseran teori terkait arms control yang kemudian penggunaannya malah menyebabkan insekuritas dan ancaman; (7) kenyataan bahwa pengalaman masa lalu yang berusaha menghentikan perang dengan regulasi dan structural naval arms control mengalami kegagalan (Rahman 2009).

Namun demikian focus dalam arms control juga dijelaskan sebagai advokasi dalam mempromosikan the operational arms control aspects of naval/maritime confidence building measures melalui tiga kategori: (1) Declaratory, menerangkan mengenai prinsip utama, termasuk kesepakatan batas wilayah, intensi negara terhadap non agresi dan non nuklir status serta aksesi dalam the Law of the Sea Convention. (2) Transparency, diukur melalui pertukaran informasi pada communications measures dengan mendirikan jaringan 
dan prosedur selama krisis misalnya; notification measures yang menyediakan pemberitahuan terkait latihan gabungan militer atau unusual deployment, observation/inspection measures, dengan secara sukarela memberikan informasi mengenai latihan kemiliteran maupun fasilitas persenjataan angkatan laut suatu negara. (3) Constraint, yang dapat dicegah melalui risk reduction measures melalui perjanjian atau kesepakatan antar angkatan (laut) bersenjata negara-negara untuk mencegah konfrontasi yang tidak diinginkan (Rahman 2009).

\section{5) Sistem Regulasi Keamanan terhadap Moda Transportasi Laut}

Regulasi terhadap transportasi maritime internasional adalah suatu isu keamanan dan perlu diatur oleh the International Maritime Organization (IMO). Regulasi yang ditetapkan oleh IMO terhadap maritime transportation system dilakukan untuk mencegah adanya dominasi dan eksploitasi terhadap hal ini oleh kelompok teroris, perompak, maupun ancaman-ancaman lain yang mungkin terjadi pada transportasi laut (kapal) di lautan di seluruh dunia. IMO dalam hal ini memiliki kewenangan untuk mengatur dan legitimasi sebagai wadah negara-negara untuk mengamankan wilayah kelautannya melalui regulasi serta kesepakatan- kesepakatan yang ada (Rahman 2009). Dalam hal ini regulasi dalam shipping (perkapalan) serta transportasi kelautan penting kemudian untuk memperketat regulasi terhadap hal ini agar terhindar dari kemungkinan adanya ancaman teroris, mengingat bahwa transportasi kelautan sangat rentan terhadap ancaman. Maka dalam hal ini regulasi yang ditetapkan oleh IMO terhadap maritime transportation system dilakukan untuk mencegah adanya dominasi dan eksploitasi terhadap hal ini oleh kelompok teroris, perompak, maupun ancamanancaman lain yang mungkin terjadi pada transportasi laut (kapal) di lautan di seluruh dunia. IMO dalam hal ini memiliki kewenangan untuk mengatur dan legitimasi sebagai wadah negara-negara untuk mengamankan wilayah kelautannya melalui regulasi serta kesepakatan- kesepakatan yang ada (Rahman 2009).

\section{HASIL DAN PEMBAHASAN}

Laut Indonesia digunakan untuk berbagai jalur lintas perdagangan kapal-kapal dari dalam maupun luar negeri untuk melakukan aktivitas perdagangan maupun ekspor impor. Dalam hal ini Laut Sulu merupakan salah satu laut yang memiliki makna strategis untuk perdagangan Indonesia, begitu juga dengan negara-negara di Asia Timur dan Pasifik. Laut Sulu digunakan sebagai jalur perdagangan yang dapat membantu tumbuhnya ekspor dari Indonesia bagian tengah dan timur yang rata-rata dilewati 10 kapal cargo setiap harinya. Sebagian besar kapal kargo yang melalui Laut Sulu mengangkut batu bara dan komoditas ke China, Jepang, Korea Selatan dan Filipina (Dursin 2016). Tidak hanya itu, wilayah perairan ini dilihat mempunyai nilai strategis karena ribuan armada tanker minyak dan armada dagang melewati rute tersebut karena potensi, letak maupun kuantitas kegiatan laut yang padat di rute tersebut. Namun keuntungan tersebut bukan cuma menimbulkan pengaruh baik saja, namun juga memiliki kecenderungan buruk karena beberapa ancaman yang kemudian muncul diantaranya. Seperti adanya pelanggaran wilayah karena posisinya yang berbatasan dengan tiga negara, konflik penangkapan ikan secara ilegal, penerobosan senjata dan buman trafficking, hingga masalah perampokan kapal dan penculikan awak kapal (maritime piracy).

Maritime piracy merupakan salah satu ancaman yang kemudian muncul dari adanya aktivitas di lautan yang dilakukan baik untuk perdagangan, militer maupun hal lainnya. Maritime piracy adalah salah satu kejahatan yang sudah lama berada di bawah yang disebut Law of Nations atau hukum yang ada di suatu negara (Presidency of the Government 2013). Terminologi "piracy" mencakup dua jenis pelanggaran yang berbeda yakni pertama, 
perampokan atau pembajakan dimana target dari serangan ini adalah untuk mencuri kargo maupun kapal maritime; kedua, penculikan yang dilakukan aktor kejahatan transnasional dengan mengancam dan menculik kapal serta awak kapal untuk mendapatkan uang tebusan (UNODC 2010). Pada tahun 2016 The International Maritime Bureau (IMB) melaporkan bahwa Laut Sulawesi-Laut Sulu mengalami peningkatan aktivitas kejahatan bajak laut dan pembajakan kapal di wilayah perairan tersebut.. Dalam laporan ReCAAP (The Regional Cooperation Agreement on Combating Piracy and Armed Robbery against Ships in Asia) sepanjang tahun 2016 terdapat 16 kali kasus penyanderaan kru kapal di Laut Sulawesi dan Laut Sulu (ReCAAP 2017). Hal ini menunjukkan bahwa terdapat adanya ancaman terhadap keamanan Maritim di Laut Sulu.

Abu SayyafGroup-ASG adalah salah satu kelompok separatis sekaligus perompak yang melakukan kejahatan pembajakan di wilayah Laut Sulu. Mereka tinggal di pulau-pulau kecil di Selatan Filipina yang bertujuan untuk melawan dan menuntut kemerdekaan pemerintah Fillipina. ASG awalnya dibentuk Filipina di bawah kelompok militan muslim pada awal tahun 1990an oleh Ustadz Abdurajak Janjalani yang memiliki kedekatan dengan Osama Bin Laden dan Ramzi Yousef (ReCAAP 2017). Dimana hal ini mengindikasikan bahwa ASG berusaha untuk mendirikan sarang Al-Qaeda di Filipina untuk menyebarkan terror (ReCAAP 2016). Kelompok ini melakukan berbagai kejahatan laut kepada siapapun yang dapat menjadi targetnya dengan menculik awak kapal dan meminta tebusan besar pada keluarga korban, perusahaan kapal, ataupun negara.

Aksi kejahatan yang dilakukan oleh ASG kemudian dilihat sebagai bentuk pergeseran politik yang pada awalnya mempersiapkan dibangunnya negara Islam di Asia Tenggara sesuai tujuan pembentukan awal kelompok ASG, namun bergeser membentuk kelompok penculik yang meminta uang tebusan ke negara-negara terkait. Aksi yang dilakukan oleh ASG juga didorong oleh kontur geografis Filipina Selatan, dimana dalam aktivitasnya diprediksi ASG mempunyai ratusan gerilyawan aktif yang dapat melakukan operasi penculikan di laut (GMA News Online n.d.).

Perekrutan pengikut dalam ASG kebanyakan berasal dari Basilan, Sulu, Tawi-Tawi, Zamboanga, dan General Santos dimana sebagian besar dari mereka direkrut dari mantan anggota MNLF atau MILF. Dalam melakukan aktivitasnya, ASG memiliki kekurangan dana untuk melancarkan aksinya, sehingga, ASG berusaha melakukan penggalangan dana atas nama gerakan islam yaitu $\mathrm{Al}$ Haratatulal-Islamiya dan juga melakukan aktivitas maritime piracy yang disertai teror untuk mendapatkan keuntungan (GMA News Online n.d.). Selain melakukan penggalangan dana melalui gerakan islam dengan nama Al Haratutlal-Islamiya, ASG juga melakukan penculikan untuk mendapatkan uang tebusan melalui aktivitas maritime piracy dan maritime terrorism. ASG dalam hal ini melakukan operasi di daerah Basilan dan daerah Sulu.

\section{Proteksi dan Konservasi Ekosistem Maritim di Laut Sulu}

Burhanudin, selaku Deputi Bidang Koordinasi Kedaulatan Maritim, Kemenko Kemaritiman RI menjelaskan bahwa Laut Sulu merupakan laut yang strategis karena letaknya di wilayah ALKI (archipelagic sea lane) II, dimana memanjang dari Selat Lombok-Selat Makassar-Laut Sulu Sulawesi yang sebagian besar dilewati oleh VLCC (kapal tanker) ukuran besar yang ingin mengekspor barang ke China tetapi tidak ingin mendapatkan antrian di Selat Malaka dan Selat Singapura, cenderung memilih untuk melewati Selat Lombok yang nantinya akan melewati Laut Sulu-Sulawesi naik ke Selat Filipina hingga sampai ke China, Jepang dsb (Burhanudin n.d.). Lebih lanjut Laut Sulu juga merupakan laut yang bertempat di puncak Segitiga Terumbu Karang Dunia, hal ini kemudian menjadikan kawasan ini sebagai kawasan konservasi kunci dunia dan ditetapkan sebagai Sulu-Sulawesi Marine Ecoregion (SSME). 
Bentang Laut Sulu-Sulawesi yang merupakan kawasan konservasi kunci berperan krusial dalam pengelolaan Segitiga Terumbu Karang dunia yang terdiri dari enam negara yakni Indonesia, Malaysia, Filipina, Papua Nugini, Timor Leste dan Kepulauan Solomon (Ambari n.d.). Dalam beberapa tahun terakhir bentang laut tersebut mendapat perlindungan dan proteksi yang ketat dari sejumlah negara terutama tiga Negara: Indonesia, Malaysia dan Filipina yang kemudian menyepakati Memorandum of Understanding (MoU) mengenai wacana pemeliharaan pada ekoregion perairan Sulawesi-Sulu (Kementerian Kelautan dan Perikanan RI 2017).

Wilayah Laut Sulu-Sulawesi itu masuk kedalam wilayah coral triangle initiative. Indonesia, Filipina dan Malaysia itu bagian dari coral triangle initiative. Pada dasarnya Indonesia bersama negara-negara telah menginisiasi hal tersebut. Ini merupakan inisiatif yang dibentuk tidak dengan pikiran bahwa belum selesainya batas maritim itu menjadi penghalang bagi kerjasama maritime ketiga negara. Hal tersebut juga menjadi contoh yang baik bahwa kerjasama konservasi dapat menjadi salah satu peluang kerjasama yang menjadi perekat antara negara-negara memiliki permasalahan perbatasan maritim yang belum selesai. Dimana hal ini juga menunjukkan bahwa kerjasama dapat tanpa necessarily negara-negara memiliki batas maritime yang sudah settle (Burhanudin n.d.). Maka sebagai upaya untuk melindungi dan memproteksi segala sumber daya yang berada di Laut Sulu, pemerintah telah melakukan perangkaian model umum untuk pengaturan Bentang Laut berkelanjutan yang merupakan hasil kesepakatan Indonesia dengan beberapa negara lainnya. Kesepakatan ini kemudian disebut sebagai Prakarsa Segitiga Karang untuk Terumbu Karang, Perikanan dan Ketahanan Pangan atau The Coral Triangle Initiative on Coral Reefs, Fisheries and Food Security (CTI-CFF) yang merupakan kesepakatan antara enam Negara yakni Indonesia, Malaysia, Papua New Gunea, Filipina, Solomon Islands, dan Timor Leste yang ditandatangani pada tahun 2009. Kesepakatan ini berisi komitmen keenam negara untuk beramai-ramai menanggulangi bahaya dari luar terhadap sumber daya pesisir dan laut di kawasan Segitiga Karang dengan luas 2,3 juta mil persegi dan meliputi Zona Ekonomi Eksklusif (ZEE) setiap negara (Coral Triangle Initiative n.d.).

Gambar 2. Peta Kawasan Segitiga Karang

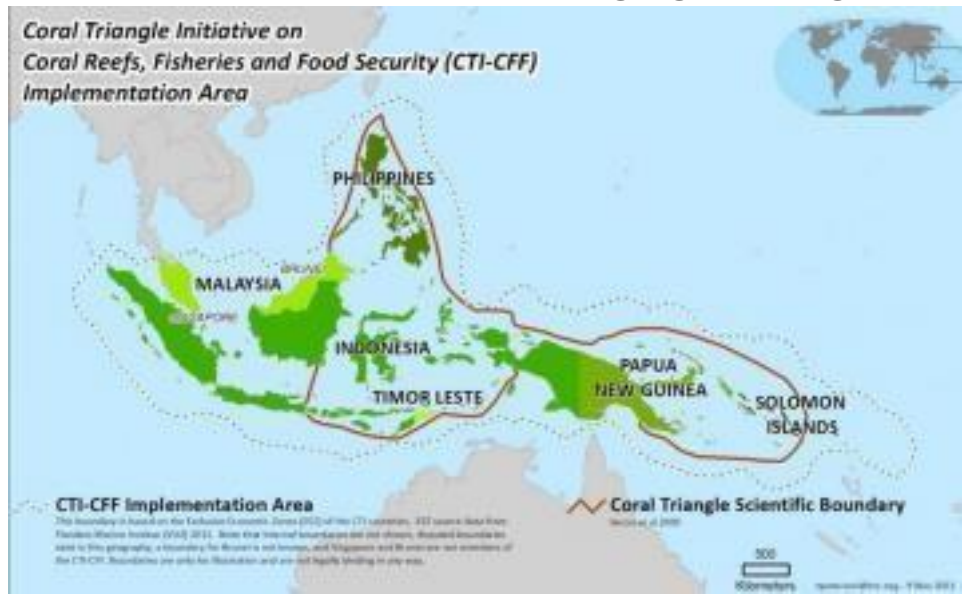

Sumber: (Coral Triangle Initiative n.d.)

Rencana the CTI-CFF Regional Plan of Action (RPOA) kemudian dibentuk agar dapat menumbuhkan dan menyalurkan usaha-usaha pengendalian dan investasi terhadap sumber daya di wilayah ini. Tujuan dari dibentuknya RPOA antara lan ialah pertama, agar Bentang Laut dapat dikelola secara efektif dengan aktivitas pemanfaatan multi sektoral dimana banyaknya pendekatan pengelolaan dan mekanisme tata kelola harus bisa diintegrasikan dan 
dikoordinasikan. Bentang Laut adalah wilayah pengambilan utilitas SDA dan perlindungan bsa dilaksanakan secara berselingan sebagai tempat yang berfungsi dalam menciptakan konstruksi ekonomi berkelanjutan. Melalui Bentang Laut ini juga negara-negara diharapkan dapat mewujudkan komitmen, target dan tujuan untuk menumbuhkan kesejahteraan sosialekonomi dan ekologis.

Kawasan Sulu-Sulawesi Marine Ecoregion (SSME) seperti yang telah dijelaskan di awal merupakan wilayah laut yang luas yang melingkupi tiga negara Indonesia, Malaysia dan Filipina. Kawasan ini memiliki nilai strategis dalam lingkup global karena keragaman hayati nya yang tinggi, ekosistem yang produktif serta utilitas ekonomi yang besar terhadap masyarakat dan komunitas global. Hal ini kemudian memberikan tekanan dari berbagai pengguna laut yang menggunakan laut ini dengan kegiatan pemanfaatan yang cukup tinggi sehingga menimbulkan berbagai potensi ancaman keamanan di wilayah ini. Namun disisi lain hal tersebut juga memberikan potensi untuk melakukan kerjasama multilateral dalam mengatasi ancaman tersebut.

Konservasi yang kemudian dilakukan pada wilayah ini (SSME) memakai pendekatan ekoregion dimana konservasi yang dilakukan melalui beberapa tahap yakni 1) survei pendahuluan, 2) penilaian aspek biofisik dan sosial ekonomi, 3) perancangan visi konservasi, 4) perancangan wacana pemeliharaan oleh berbagai pemangku kepentingan serta 5) penentuan wacana konservasi atau pemeliharaan dan pelaksanaannya di Negara- negara terkait (Coral Triangle Initiative n.d.).

Selama proses perencanaan, berbagai aktivitas konservasi atau pemeliharaan dan pembangunan kapasitas (capacity building) dilakukan secara paralel dengan mengikutsertakan berbagai pemangku kepentingan terkait. Penetapan kawasan SSME kemudian secara resmi dilaksanakan dengan penandatanganan Tri National Memorandum of Understanding (2006-2016) yang diratifikasi oleh tiga negara. Mekanisme yang mengatur komitmen ketiga Negara di kawasan SSME ini kemudian dirancang untuk melaksanakan Rencana Konservasi di tingkat nasional dan regional.

Namun upaya konservasi dan proteksi yang dilakukan oleh pemerintah Indonesia lebih menekankan pada kegiatan konservasi dan proteksi yang dilakukan secara bersama dan terkoordinasi dengan negara lain. Mengingat letak perairan Sulu yang juga berada diantara Sabah (Malaysia) dan Filipina, menyebabkan faktor historis menjadi hal yang penting untuk dipertimbangkan. Laut Sulu secara historis merupakan laut yang kepemilikannya diklaim oleh Kerajaan Sulu yang berada Filipina, sementara dari pihak Malaysia laut ini dianggap sebagai laut yang merupakan bagian dari kedaulatannya. Namun secara singkat Kerajaan Sulu (Filipina) menganggap bahwa Sabah yang notabene terletak di Malaysia masih menjadi wilayah tradisional kekuasaan kerajaan Sulu. Sehingga isu konservasi dan proteksi mengenai sumber daya alam yang ada di perairan tersebut masih menjadi hal yang sensitif bagi Malaysia maupun Filipina untuk dibuka secara terang-terangan kepada negara lain (Ramsi 2018). Indonesia dalam hal ini kemudian berperan sebagai penengah (honest broker) yang melakukan pendekatan kepada kedua negara bahwa setiap negara memiliki wilayahnya masing-masing atas laut tersebut berdasarkan kedaulatannya.

Maka dalam hal ini upaya konservasi dan proteksi sumber daya laut baik yang bisa diperbaharui ataupun yang tidak bisa diperbaharui masih dilakukan secara kolektif oleh Indonesia dengan Malaysia dan Filipina serta beberapa negara lainnya. Selain karena negaranegara menyadari betul bahwa ancaman transnasional terhadap sumber daya di perairan Sulu makin banyak terjadi, hal ini juga dilakukan karena letak geografis Laut Sulu. Laut Sulu yang tidak hanya wilayah kedaulatan satu negara saja, melainkan laut yang dikelilingi oleh berbagai negara yang masing-masing mempunyai tanggung jawab untuk berperan dalam usaha proteksi dan keamanan di wilayah ini. 
Disisi lain hal ini juga dilihat sebagai suatu upaya pengembangan kawasan yang berfokus pada pembenahan kerusakan ekosistem dan SDA, ketidakadilan dan ketidakmerataan pembangunan di kawasan tertentu agar masalah ekonomi yang nantinya dapat menimbulkan ancaman di wilayah perairan dapat dikurangi. Pembenahan yang dilakukan tidak hanya dalam tataran keamanan, tapi juga pembangunan sebagai upaya pemerataan.

Pendekatan ini kemudian menunjukkan bahwa dalam upaya untuk mengatasi masalah keamanan maritime tidak melulu harus berfokus pada pendekatan keamanan dan aspek tradisionalnya saja, melainkan perlu untuk dilihat dengan pendekatan pembangunan. Melalui perspektif ini Chris Rahman ingin memaparkan bahwa terdapat kerangka yang lebih besar yang perlu dilihat agar suatu negara dapat mengatasi permasalahan yang terjadi di lautan. Perspektif ini juga berusaha menunjukkan bahwa untuk menyelesaikan permasalahan keamanan di laut perlu untuk dilihat akar masalahnya, seperti misalnya permasalahan ekonomi, adanya ketidak merataan pembangunan di sekitar kawasan tersebut sehingga kawasan tersebut menjadi sarang penyelundup atau markas penyamun yang kemudian dapat menimbulkan peluang kejahatan masuk ke perairan tersebut.

Maka dalam hal ini penulis melihat bahwa Chris Rahman berupaya untuk membedah hal tersebut dengan melihat bagaimana upaya proteksi yang telah dilakukan oleh negara sebagai suatu kesatuan kerangka yang juga perlu dilihat untuk mengetahui keamanan maritime suatu negara secara utuh. Upaya proteksi dan konservasi yang dilakukan di perairan Sulu-Sulawesi melalui SSME dan CTI-CFF kemudian diharapkan dapat menjadi suatu langkah untuk memperbaiki dan menjaga seluruh sumber daya yang ada di Laut Sulu yang nantinya dapat dikelola oleh negara- negara agar dapat dimanfaatkan untuk kemakmuran rakyat sekitar. Pendekatan ini kemudian penulis lihat belum dapat menjelaskan strategi keamanan Indonesia dalam upayanya untuk menanggulangi maritime piracy yang terjadi di Laut Sulu. Karena pendekatan ini sifatnya lebih menekankan melihat di sisi non tradisionalnya, maka penulis melihat bahwa pendekatan ini lebih cocok untuk menjadi ukuran dalam upaya pencegahan daripada strategi keamanan maritime suatu negara.

\section{Tata Kelola Wilayah Kelautan}

Pendekatan kedua yang dijelaskan oleh Chris Rahman menjelaskan mengenai ocean governance yang melihat dengan menggunakan pendekatan manajemen (management approach). Pendekatan ini juga memiliki bias yang kuat dalam lingkungan kelautan, namun berbeda dengan pandangan fundamentalis yang menempatkan hal tersebut dalam politik internasional dan kerangka hukum yang berisikan konteks- konteks manajemen kelautan. Pendekatan ocean governance lebih menekankan pada upaya untuk mencapai suatu "rezim maritim yang stabil" berdasarkan prinsip-prinsip dalam Law of the Sea Convention (LOCS) dengan melakukan penegakan dan pengimplementasian terhadap konvensi tersebut yang merupakan pertimbangan utama dalam pendekatan ini (Rahman 2009).

Lebih lanjut Chris Rahman menjelaskan bahwa suatu tata kelola kelautan (ocean governance) yang efektif membutuhkan tidak hanya kerjasama regional yang efektif, melainkan kerjasama internasional perlu dilakukan oleh negara-negara kepulauan (coastal states) melalui masing- masing zona dan yurisdiksi maritimnya. Pendekatan ini kemudian disebut juga dengan pendekatan manajemen yang melihat pada upaya negara dalam menanggulangi ancaman dengan keikutsertaannya dalam berbagai rezim dan tata kelola global mengenai kelautan secara umum dan keamanan maritim secara khusus. Ocean governance lebih lanjut dilihat sebagai suatu industry pertumbuhan global untuk organisasi internasional, pemerintah, institusi maupun organisasi non pemerintah, dsb. Kemudian pendekatan manajemen kelautan lebih berfokus pada promosi, penguatan dan pertahan baik secara 
politik, retorikal maupun institusional di dalam system untuk melihat suatu rezim keamanan maritime yang stabil.

Dalam melihat pendekatan tata kelola kelautan (ocean governance) yang juga disebut sebagai pendekatan manajemen oleh Chris Rahman, penulis kemudian menemukan indikator hal ini yang dapat dilihat melalui bagaimana keterlibatan dan kepatuhan suatu negara dalam sistem dan kerangka global yakni: global governance, maritime security regime serta law of the sea convention.

\section{- Tata Kelola Global terkait Isu Kelautan}

Dalam jurnalnya Chris Rahman menjelaskan bahwa global governance dideskripsikan sebagai suatu implementasi dari seperangkat aturan secara tertulis maupun praktek yang ditujukan untuk membentuk sebuah tata kelola (pemerintahan) kelautan yang bertujuan mengatur penggunaan dan pemanfaatan laut beserta penggunanya (Rahman 2009). Dalam hal ini ketiadaan world government dalam lingkup global mengakibatkan pembentukan suatu rezim baru memerlukan izin negara agar seperangkat aturan yang tertuang dalam rezim tersebut dapat dilaksanakan dan dipraktekkan secara nyata melalui negosiasi (Rahman 2009).

Dalam kaitannya dengan keterlibatan Indonesia dalam ocean governance dan hubungannya dengan Laut Sulu, Burhanudin menjelaskan bahwa Ocean governance di laut Sulu ya pertama CTI-CFF itu dimana Indonesia sebagai leader initiator-nya. Hal ini karena Indonesia menyadari betul bahwa kondisi lingkungan yang rusak itu berakibat banyak, seperti pada kemiskinan, pertumbuhan SDM yang tidak maksimal, termasuk keamanan maritime. Oleh karena itu, Indonesia mengupayakan implementasi CTI-CFF, coral triangle initiative and coral reefs, fisheries and food security dalam agenda ocean governance. Indonesia tidak hanya aktif dalam mengupayakan implementasi dan kebijakan yang berkaitan dengan agenda maritimenya saja, melainkan juga aktif dalam agenda forum-forum internasional.

Seperti yang telah dijelaskan oleh Burhanudin bahwa CTI-CFF merupakan salah satu upaya Indonesia untuk turut berpartisipasi dalam pembentukan tata kelola global yang berfokus di bidang kelautan. Dalam hal ini Indonesia menyadari betul bahwa permasalahan- permasalahan yang muncul di laut seperti terjadinya perompakan dan pembajakan kapal, penculikan, penyelundupan barang, dsb merupakan akibat dan dampak yang ditimbulkan dari tidak selesainya permasalahan yang terjadi di daratan. Permasalahan ekonomi seperti kemiskinan dan pembangunan yang tidak merata misalnya kemudian memicu para pelaku (aktor) kejahatan untuk melakukan aksinya. Maka Indonesia dalam hal ini menyadari betul bahwa penanggulangan masalah-masalah di lautan terutama yang berhubungan dengan maritime piracy tidak melulu hanya dilaksanakan menggunakan pendekatan tradisional dan militeristik melainkan juga perlu diselesaikan dengan ikut serta terlibat dalam kerangka tata kelola global dengan melakukan kerjasama dengan negara-negara untuk menjaga keamanan wilayah perairan dan lautan.

Maka dalam hal ini dapat dilihat bahwa partisipasi Indonesia dalam pembentukan CTI-CFF (The Coral Triangle Initiative on Coral Reefs, Fisheries and Food Security) merupakan suatu implementasi dari kesadaran Indonesia akan pentingnya isu keamanan maritime yang tertuang dalam berbagai kerangka kerja ocean governance (Burhanudin n.d.). Hal ini juga dilakukan sejalan dengan implementasi untuk mendukung Indonesia menjadi negara poros maritime dunia.

Hal lain yang dilakukan Indonesia untuk menunjukkan keseriusannya terhadap hal ini adalah adanya keterlibatan Indonesia yang secara aktif berperan dalam forumforum internasional seperti Core Ocean Conference, IORA (Indian Ocean Rim 
Association) leader summit, IORA ministerial blue economic conference mengenai pengembangan ekonomi biru di tingkat ministrial, Archipelagic an island state forum yang merupakan forum negara-negara pulau atau kepulauan yang bertujuan salah satunya untuk membentuk suatu ocean governance selain soal development dan perubahan iklim (Burhanudin n.d.).

Ocean governance dalam hal ini juga ditujukan untuk menekankan bahwa penting untuk membentuk suatu sistem ataupun rezim yang berisi aturan serta dapat ditaati oleh negara-negara terkait penggunaan laut. Hal ini dimaksudkan untuk menyediakan wadah untuk menyelesaikan konflik yang mungkin terjadi karena penyalahgunaan manfaat kelautan. Dalam kaitannya dengan aktivitas pembajakan dan penculikan (piracy) yang terjadi di Laut Sulu keterlibatan Indonesia dalam berbagai forum maritime internasional merupakan salah satu upaya untuk menanggulangi hal tersebut.

\section{- Rezim Keamanan Maritim}

Maritime security regime atau rezim keamanan maritime lebih lanjut dilihat sebagai suatu bentuk penguatan dan pertahanan yang tertuang dalam bentuk seperangkat aturan (rezim). Dimana menurut Chris Rahman rezim keamanan maritime nantinya juga dapat menjadi tolak ukur untuk melihat apakah pendekatan manajemen yang meletakkan pada kerangka besar ocean governance sebagai suatu aspek yang implementatif dalam upaya mencapai hal tersebut. Indonesia yang merupakan negara kesatuan dengan sebagian besar wilayahnya berupa lautan yang juga berfungsi sebagai penyatu daratan atau pulaupulau yang terdapat didalamnya membuat keberadaan laut memiliki arti yang sangat penting. Indonesia dalam hal ini mengenal konsep laut dalam yang terdapat dalam hukum laut Indonesia yang merupakan hasil dari Deklarasi Juanda. Deklarasi Djuanda yang mengandung konsepsi nusantara sebagai negara maritim menjadi acuan bagi pemerintah Indonesia untuk memperjuangkan pengakuan internasional dalam kedaulatan dan hak lautnya. Deklarasi Djuanda dilihat sebagai suatu landasan struktural dan legalitas bagi proses integrasi nasional Indonesia sebagai negara maritim (Ramsi 2018).

Lebih lanjut ketika menjelaskan mengenai CTI-CFF sebagai bagian dari upaya Indonesia dalam membangun dan berkontribusi dalam ocean governance, Burhanudin menjelaskan bahwa dalam hubungannya dengan CTI-CFF sebagai bagian dari rezim keamanan yang khusus dibentuk bahwa dalam hubungannya dengan rezim keamanan maritime tidak langsung masuk ke rezim keamanan. Namun keamanan juga berbicara mengenai keamanan dan ketahanan. Dimana keamanan itu berbicara mengenai aspek keamanannya (security) nya dan ketahanan itu aspek resilience nya. Aspek resilience itu bisa banyak, bisa dari kemampuan adaptasi terhadap perubahan iklim, bisa berkaitan dengan bagaimana negara menangani persoalan pencemaran lingkungan, ataupun mengenai ekosistem yang berkelanjutan. Nah hal tersebut baru bisa masuk yang ini, CTICFF ini (Burhanudin n.d.).

Dalam hal rezim keamanan maritime perlu dilihat bahwa keamanan memiliki dua aspek yakni keamanan yang mencakup aspek security yang tercakup dalam CTI-CFF dan ketahanan yang mencakup aspek resilience melalui kemampuan adaptasi terhadap perubahan iklim, penanganan terhadap persoalan pencemaran lingkungan dan penanganan ekosistem berkelanjutan yang termasuk dalam inisiatif Indonesia dalam archipelagic an island state forum (Burhanudin n.d.).

Selain itu a cooperation agreement related crimes and illegal fisheries merupakan suatu bentuk keikutsertaan Indonesia dalam ocean governance yang secara spesifik berbicara mengenai maritime security dan maritime safety. Penetapan traffic separation skin di Selat Lombok melalui IMO juga merupakan upaya Indonesia dalam membuat 
suatu rezim keamanan maritime. Maka dalam hal ini dapat dilihat bahwa Indonesia telah berperan serta dan turut andil dalam kaitannya dengan ocean governance terlebih rezim keamanan maritim yang dibuat untuk mengatur dan menyelesaikan permasalahanpermasalahan yang muncul di wilayah perairan.

\section{- Law of the Sea Convention (LOSC)}

Chris Rahman kemudian melihat bahwa terdapat dua masalah potensial dalam keamanan maritim, terlebih yang terdapat di wilayah Asia-Pasifik. Dimana dalam hal ini sebagaimana yang telah dituliskan oleh Sam Bateman sebelumnya mengenai Law of the Sea Convention dijelaskan bahwa terdapat beberapa pembatasan penting dalam fondasi membangun suatu rezim keamanan maritim di kawasan (regional). Lebih lanjut dalam merumuskan hal tersebut juga dipengaruhi adanya limitasi dan kompleksitas dalam LOSC yang terkadang membangun sebuah ambiguitas dan kelambatan dalam membangun law of the sea di negara-negara. Hal ini juga merupakan bukti bahwa terdapat permasalahan (issues) yang tidak dapat dihindari. Untuk menghindari hal tersebut maka perlu adanya suatu framework yang diperlukan untuk membangun suatu hubungan internasional yang damai di lautan agar tercapainya rezim keamanan maritime yang stabil dalam suatu ocean governance yang efektif.

Dalam hal ini UNCLOS kemudian dilihat sebagai suatu kerangka yang dapat digunakan untuk mencapai hal tersebut. Dimana sebagai negara yang turut berpartisipasi sebagai pihak dari UNCLOS 1982, Indonesia memiliki kedaulatan penuh atas wilayah perairan yang terdiri atas perairan pedalaman, perairan kepulauan dan laut teritorial (Kemenko Kemaritiman n.d.). Kedaulatan Indonesia selain itu juga mencakup dasar laut dan seisinya, serta ruang udara di atas perairan tersebut termasuk seluruh sumber daya alam yang terkandung di dalamnya. Maka dalam hal ini pemerintah Indonesia wajib untuk mengelola dengan baik dan berkelanjutan sesuai dengan hak kedaulatan yang dimilikinya (Kemenko Kemaritiman n.d.).

Indonesia selain itu juga memiliki hak berdaulat dan kewenangan tertentu di kawasan yurisdiksi Indonesia di luar laut teritorial yang terdiri atas Zona Tambahan, Zona Ekonomi Eksklusif (ZEE), dan Landasan Kontinen. Sementara laut teritorial Indonesia selebar 12 mil laut yang diukur dari garis pangkal kepulauan Indonesia. Dimana dalam hal ini zona maritim tersebut berbatasan dengan Negara tetangga yang batas terluarnya diukur dan ditetapkan melalui kesepakatan dengan tetangga, sesuai dengan hukum internasional dalam hal ini UNCLOS 1982 (Kemenko Kemaritiman n.d.).

Maka dalam rangka memenuhi kewajiban UNCLOS 1982 Indonesia juga telah menyampaikan ke Sekretariat Jenderal Perserikatan Bangsa-Bangsa (Sekjen PBB) mengenai titik-titik dasar, garis pangkal dan batas-batas maritim dengan negara tetangga (Kemenko Kemaritiman n.d.). Proses teknis lain seperti verifikasi jumlah pulau dan panjang pantai juga dilakukan terus menerus sebagai upaya untuk menjaga batas-batas maritim Indonesia. Hal ini juga penting dilakukan untuk mengetahui berbagai fakta geografis Indonesia agar nantinya Indonesia dapat melakukan upaya penjagaan kedaulatan Indonesia atas pulau-pulau terluar dan perairannya. Selain itu implementasi peraturan-peraturan dan nilai-nilai dalam UNCLOS yang dilakukan oleh Indonesia melalui: pertama, keamanan super regional; kedua, menerjemahkan dan mengimplementasikan aturan-aturan dalam UNCLOS pada tindak dan kasus kejahatan transnasional yang terjadi di wilayah perairan Indonesia termasuk di dalamnya illegal fishing, maritime piracy, money laundering ataupun penyelundupan manusia yang dilakukan di lautan. 
Dalam hal ini secara garis besar pendekatan manajemen melalui kacamata ocean governance melihat pada kerangka sistem dan aturan yang mengatur tentang tata kelola kemaritiman. Pada perspektif ini masing-masing indikator seperti global governance, maritime security rezime dan law of the sea convention memiliki keterkaitan satu sama lain dalam upaya menjelaskan ocean governance yang telah dilakukan oleh suatu negara. Dalam kasus ini penulis ingin menunjukkan bahwa variabel ini memiliki keterkaitan erat dalam menjelaskan bagaimana strategi keamanan maritime yang dilakukan oleh Indonesia dalam menanggulangi maritime piracy di tataran global. Yang kemudian tercermin melalui keterlibatan Indonesia akan berbagai forum-forum maritime internasional yang juga membahas isu keamanan maritim di kawasan ataupun dalam kerangka yang lebih besar. Namun pendekatan non tradisional ini penulis rasa belum cukup untuk menjelaskan secara utuh strategi keamanan maritime Indonesia dalam menanggulangi maritime piracy di Laut Sulu. Penulis melihat bahwa pendekatan ini lebih ke upaya pencegahan secara tidak langsung daripada strategi yang dapat diterapkan secara langsung dalam menanggulangi ancaman yang terjadi di Laut Sulu.

\section{Perlindungan Perbatasan Laut}

Chris Rahman menjelaskan bahwa maritime border protection merupakan upaya yang dilakukan dengan meningkatkan proteksi di kawasan perbatasan untuk menghindari adanya ancaman yang mungkin terjadi di wilayah perairan. Penjagaan sumber daya kelautan di wilayah perbatasan dengan tetap memperhatikan nasional yurisdiksi masing- masing negara menjadi hal yang penting dalam mengukur proteksi perbatasan di laut telah dilaksanakan dengan baik atau belum. Proteksi wilayah perbatasan di lautan menjadi penting dilakukan sebagai upaya untuk menegakkan kedaulatan negara atas hak dalam mengelola dan pemanfaatan kelautan.

Menanggapi kasus kejahatan yang terjadi di Laut Sulu Indonesia dalam hal ini telah berupaya untuk melakukan tindakan proteksi perbatasan yang dilakukan bersama dengan Malaysia dan Filipina sebagai negara yang juga berbatasan langsung dengan perairan tersebut. Hal ini kemudian dituangkan melalui kerangka Kerjasama Trilateral yang dilakukan oleh Indonesia-Malaysia-Filipina yang didasarkan pada joint declaration pada langkah-langkah yang harus dilakukan segera untuk menangani isu keamanan di area maritime yang menjadi konsen antara tiga negara tersebut. Dalam hal ini ketiga negara sepakat untuk melakukan: (Kemlu n.d.)

1. To conduct patrol among the three countries using existing mechanism as a modality;

2. To render immediate assistance for the safety of people and ships in distress within the maritime areas of common concern;

3. To establish a national focal point among the three countries to facilitate timely sharing of information and intelligence as well as coordination in the event of emergency and security threats; and

4. To establish a hotline of communication among the three counties to better facilitate coordination during emergency situations and security threats.

Terdapat empat operasional kerjasama yang dilakukan antara lain patrol maritim, bantuan darurat, pertukaran informasi intelijen dan jalur komunikasi. Kemudian berdasarkan hasil wawancara yang dilakukan penulis dengan Kolonel Oktaheroe Ramsi selaku Kasubdit Multilateral, Direktorat Kerjasama Internasional, Kementerian Pertahanan RI mengatakan bahwa menanggapi ancaman transnasional yang sedang marak terjadi di wilayah perairan khususnya dalam hal ini di Laut Sulu pada tahun 2016 yakni perompakan, penculikan dan pembajakan kapal, negara-negara berupaya untuk mengatasi hal tersebut dengan berbagai cara. Menilik dari kasus kejahatan yang banyak terjadi di Selat Malaka sebelumnya, efektivitas 
Malacca Strait Sea Patrol (MSSP) yang merupakan upaya dari pemerintah Indonesia, Singapura serta Malaysia mampu menekan tindak kriminal yang terjadi di Selat Malaka hingga hampir $0 \%$. Kawasan yang tadinya memiliki status yang berbahaya kemudian berubah menjadi relatif aman setelah dilakukan patrol terkoordinasi antar negara tersebut. Kemudian negara-negara berupaya untuk membuat duplikat patrol terkoordinasi untuk tindak kriminal yang terjadi di Laut Sulu-Sulawesi melalui kerangka kerjasama tiga negara Trilateral Cooperation Agreement (TCA) (Ramsi 2018). Dalam hal ini dapat dilihat bahwa upaya yang dahulu dilakukan di Selat Malaka dalam mengurangi dan menanggulangi tindak kejahatan yang terjadi di lautan melalui kerangka kerjasama MSSP antara Indonesia, Malaysia dan Singapura terbukti efektif dengan adanya patroli di lautan dan eyes in the sky sebagai upaya patroli negara-negara melalui udara. Maka pemerintah Indonesia kemudian mencoba upaya yang sama dalam menanggulangi ancaman di laut Sulu.

Upaya proteksi di wilayah perbatasan dalam rangka menjaga kedaulatan dan hak negara di lautan dilakukan melalui suatu kerangka kerjasama yang disebut dengan Trilateral Cooperation Agreement (TCA) antara Indonesia, Malaysia dan Filipina. Kerangka kerjasama ini kemudian diresmikan pada Juni 2017 melalui soft launching di Tarakan yang dihadiri oleh masing-masing Menteri Pertahanan Indonesia, Malaysia dan Filipina serta observer dari Brunei Darussalam dan Singapura yang bertugas untuk melaksanakan operasi imbangan. Kolonel Oktaheroe menjelaskan bahwa TCA yang merupakan patrol terkoordinasi tiga negara berisi semua upaya yang berkaitan dengan distress of the ships on the sea. Dimana TCA ini kemudian mencakup TMP (Trilateral Maritime Patrol), dan diperluas cakupannya dengan dibentuknya TAP (Trilateral Air Patrol) serta perketatan penjagaan keamanan di darat melalui Land Exercise untuk meningkatkan kemampuan pasukan-pasukan hingga pengejaran pelaku kejahatan di laut yang kabur ke darat (Ramsi 2018). Maka dalam hal ini dapat dilihat bahwa Trilateral Cooperation Agreement (TCA) merupakan suatu bentuk kerangka kerjasama yang mencakup patroli maritime terkoordinasi yang tidak hanya terbatas di wilayah laut melalui Trilateral Maritime Patrol (TMP), melainkan juga mencakup Trilateral Air Patrol (TAP) yang dilakukan di udara serta Land Exercise yang dilakukan di darat dalam rangka memperkuat pertahanan di wilayah perbatasan dalam menanggulangi ancaman- ancaman yang ada (Ramsi 2018).

Selain itu dilakukan juga port visit dengan melibatkan crew kapal ke lokasi pemanfaatan yang telah disediakan dengan tujuan untuk membangun capacity building dan kepercayaan dari masing-masing personil yang melakukan pengamanan di laut tersebut. Port visit ini dilaksanakan sebanyak dua kali tiap satu tahun dengan berbagai kegiatan selain melakukan kunjungan seperti melakukan parachute exercise maupun drill yang ditujukan untuk penanganan dan penangkapan (Ramsi 2018). Dalam situasi normal patroli maritime dan bantuan darurat yang dilakukan oleh angkatan bersenjata dilakukan secara terkoordinasi oleh tiap-tiap negara di wilayah yurisdiksinya masing-masing. Sehingga patroli ini disebut sebagai patroli terkoordinasi daripada joint patrol (Yusup 2018). Selain patroli terkoordinasi upaya lain yang dilakukan adalah dengan sharing informasi antara Indonesia, Malaysia dan Filipina terkait ancaman yang terjadi di Laut Sulu. Dimana hal ini juga difasilitasi dengan dibentuknya Maritime Command Center (MCC) yang digunakan untuk melakukan koordinasi lintas dan memberikan respon tanggap darurat terkait insiden yang terjadi di tiap-tiap yurisdiksi negara. Maka dalam hal ini secara garis besar upaya maritime border protection yang dilakukan oleh pemerintah Indonesia adalah dengan menginisiasi pembentukan kerangka kerjasama TCA yang mencakup seluruh hal yang perlu dilakukan negara untuk mengatasi ancaman dan tindak kejahatan di Laut Sulu. 


\section{- Joint Operation}

Joint operation atau operasi gabungan dapat diartikan sebagai suatu terminologi umum dalam mendeskripsikan suatu tindakan militer yang dilakukan melalui serangkaian upaya perkuatan bersama (joint forces) antar negara, atau dalam menjalin hubungan dalam pelaksanaan service forces namun dalam hal ini negara-negara tidak membentuk suatu pasukan gabungan (joint forces).

Dalam menjelaskan apakah ada keterlibatan Indonesia dalam joint operation yang dilakukan dengan negara-negara dalam upaya proteksi batas-batas maritime dan yurisdiksi di kawasan perairan Sulu Laksma Yusup mengemukakan bahwa latihan militer belum pernah dilaksanakan dan tidak ada rencana untuk melaksanakannya di perairan Sulu, namun berupaya mengembangkan patrol terkoordinasi untuk mengurangi penculikan dan kejahatan (Yusup 2018).

Sehingga dalam hal ini operasi yang dilakukan dan dikembangkan baru sebatas patroli terkoordinasi yang dirasa sudah cukup untuk mengurangi penculikan dan kejahatan di Laut Sulu. Hal ini dibuktikan dengan semenjak diadakannya patroli terkoordinasi di tahun 2017, jumlah kejahatan yang terjadi di tahun itu boleh dikatakan hampir tidak ada. Jumlah ini dapat dikatakan mengalami pengurangan yang drastic dibanding pada tahun 2016 (Yusup 2018). Selain itu kerjasama yang dilakukan dalam bentuk tukar menukar informasi yang dibarengi dengan patroli terkoordinasi dan kehadiran operasi sehari-hari juga dirasa mengurangi jumlah kejahatan dengan cukup signifikan.

Namun upaya untuk melakukan latihan gabungan kedepannya telah dicanangkan oleh ketiga negara yang telah mencapai pada tahap final planning conference menurut Kolonel Kav Oktaheroe Ramsi. Dimana dalam hal ini latihan gabungan yang dilakukan merupakan latihan yang dilakukan di darat (land exercise) yang akan dilakukan secara sistematis dan berkala nantinya. Latihan ini kemudian akan dilakukan secara berkesinambungan yang dimaksudkan untuk memperkuat kualitas dari tiap-tiap personel yang akan terlibat di kegiatan pengamanan. Hal ini juga diharapkan akan dapat memberikan sinyal kepada dunia bahwa negara-negara litoral di sekitar Laut Sulu juga memiliki kemampuan untuk menjaga keamanan di wilayah teritorialnya masing-masing (Ramsi 2018; Yusup 2018).

\section{- Maritime Patrol}

Maritime patrol merupakan upaya patroli yang dilakukan oleh angkatan laut dalam menanggulangi kemungkinan ancaman yang terjadi di laut. Dalam upaya untuk menanggulangi ancaman-ancaman tersebut termasuk penculikan dan pembajakan (piracy). Maritime Patrol dalam hal ini dilakukan sebagai upaya Indonesia untuk menanggulangi dan mencegah aktivitas kejahatan maritime terjadi di Laut Sulu bersama dengan kedua negara lainnya. Maritime Patrol kemudian disebut dengan TMP (Trilateral Maritime Patrol). Dalam hal ini Laksma Yusup dalam hal ini mengatakan bahwa Indonesia menjalin kerjasama dengan ketiga negara itu untuk menjaga stabilitas keamanan perairan khususnya di perairan Sulu dalam bentuk joint patrol yang disebut trilateral." (Yusup 2018).

Sejak 2004 beberapa Negara seperti Indonesia, Malaysia, Singapura dan Thailand melakukan langkah serupa untuk bergabung dalam penjagaan laut dan udara yang juga sejalan dengan upaya untuk menanggulangi pembajakan dan perampokan bersenjata (piracy and armed robbery). Dalam hal ini Filipina, Indonesia dan Malaysia kemudian merumuskan suatu perjanjian kerjasama yang disepakati oleh tiga negara (tripartite cooperation agreement) dalam memperkuat kerjasama keamanan maritim di tiga wilayah perbatasan (tri-border sea areas) Laut Sulu dan Sulawesi melalui penandatanganan terkait 
pertukaran informasi dan pembentukan suatu perjanjian prosedur komunikasi ada $7 \mathrm{Mei}$ 2002 (Febrica 2017). Perjanjian ini kemudian dibahas diantara Kementerian Luar Negeri, Kementerian Pertahanan, kepolisian serta Kementerian Koordinator Bidang Politik Hukum dan Keamanan Republik Indonesia. Kesepakatan yang tercakup dalam kerjasama tersebut salah satunya membawahi perjanjian mengenai pertukaran informasi (information exchange) termasuk pertukaran informasi antar negara, latihan dan pelatihan maritime, serta adanya pembagian informasi mengenai daftar penumpang penerbangan serta database pada sidik jari yang bersangkutan (Febrica 2017).

Pada tahun 2016 inisiasi patroli di Laut Sulu yang dilakukan oleh Indonesia, Malaysia dan Filipina kemudian resmi didirikan yang juga dikenal dengan INDOMALPHI. Keterlibatan Filipina dalam joint patrol atau patroli terkoordinasi ini juga diharapkan dapat menghentikan penculikan dan pencegah pergerakan kelompokkelompok militan bersenjata dalam wilayah tersebut yang merupakan ancaman bagi kawasan. Ketiga Negara kemudian juga meresmikan trilateral air patrol pada Oktober 2017 sebagai upaya untuk mendorong penanggulangan kejahatan transnasional yang terjadi di lautan selain upaya yang dilakukan secara langsung di lautan dengan maritime patrol (Parameswaran 2017).

Dalam hal ini beberapa Negara seperti Singapura, Jepang dan Australia juga turut mendorong upaya tersebut dengan menawarkan bantuan berupa keikutsertaan dalam patroli secara regional (regional patrols) maupun dengan memberikan bantuan dana kepada aktor yang bersangkutan (aid local actors). Ketiga Negara juga membangun sebuah infrastruktur yakni pusat komando maritime (Maritime Command Centers) yang terletak di Bongao, Tawau dan Tarakan sebagai upaya untuk mengurangi dan menanggulangi maritime piracy maupun armed robbery yang terjadi di Perairan Sulawesi-Sulu (ReCAAP 2017). Pusat komando maritim ini kemudian didirikan sebagai upaya dalam mensinergikan laporan patroli yang didapat melalui udara yang kemudian ditransfer kepada patroli di laut yang pada akhirnya disambungkan ke masing-masing markas kemiliteran tiap negara, yakni Mabes TNI (Indonesia), MKN (Malaysia) serta DND (Filipina) (Ramsi 2018).

Gambar 3. Location of Asia Maritime Command Centers

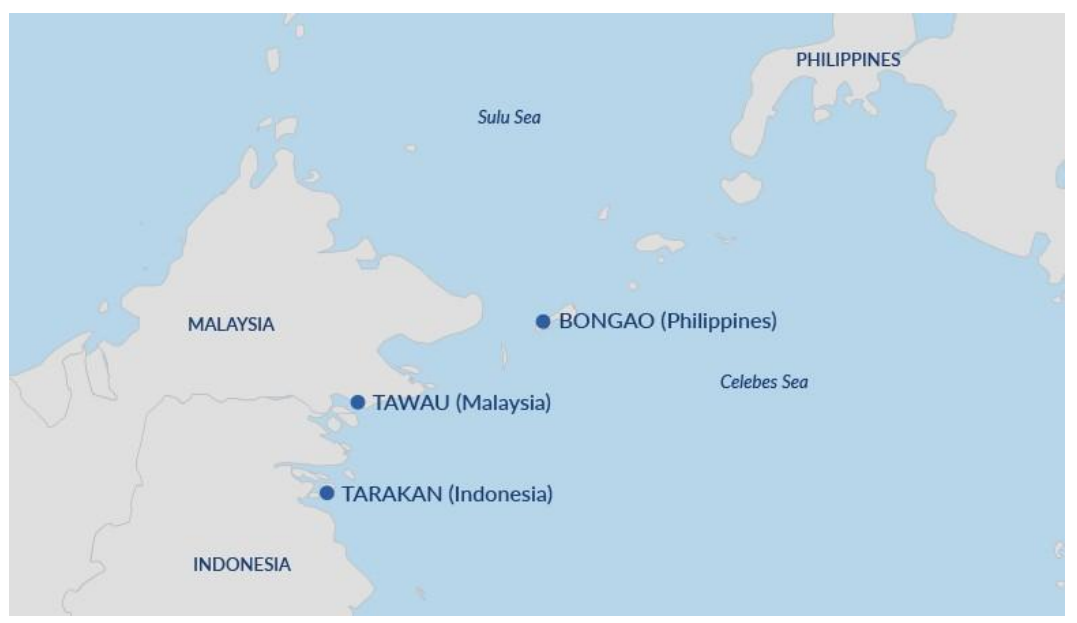

Sumber: Oceans Beyond Piracy (2017)

Gambar diatas merupakan uraian letak pusat komando maritime (maritime command center) yang merupakan upaya tiga negara dalam memantau kejadian dan ancaman yang mungkin terjadi di perairan Sulu. Dalam hal ini Laksma Yusup mengatakan bahwa 
pelaksanaan joint patrol harus dikemas melalui suatu kesepakatan (MoU) dalam penyusunan standard operational procedure (SOP) terhadap penggunaan alutsista dan peralatan militer untuk menghormati dan menghargai regulasi dari tiap negara. Namun sementara ini pelaksanaan patroli di laut masih dilakukan di wilayah masing-masing dengan melakukan informasi sharing data- data intelijen diantara ketiga negara melalui MCC (Ramsi 2018; Yusup 2018). Sehingga maritime command center dalam hal ini difungsikan sebagai suatu alat untuk mempermudah upaya informasi sharing data-data intelijen untuk saling tukar menukar informasi agar kecenderungan pembajakan atau penculikan di lautan dapat dihindari. Setiap aktivitas dan termasuk pelintas yang melewati perairan Sulu dari Indonesia menuju Filipina atau Malaysia dan sebaliknya akan saling dikirim informasi untuk diantisipasi tiap-tiap negara dan melakukan patroli di lautan sesegera mungkin. Agar tidak sampai terjadi kasus pembajakan maupun penculikan ABK maupun kapal yang melintas di perairan tersebut.

Trilateral maritime patrol ini juga dibentuk sebagai respon untuk memperlihatkan usaha ketiga negara dalam meningkatkan keamanan regional dan mengurangi ancaman maritime piracy di Laut Sulu (Wee 2017). Indonesia, Malaysia dan Filipina juga menyetujui untuk menjadikan coordinated maritime patrol sebagai salah satu rencana utama untuk mencegah dan menanggulangi kemungkinan peningkatan kejahatan dan ancaman yang terjadi di Laut Sulu.

\section{Gambar 4. Suggested Patrol Route along Transit Corridor within Area of Maritime Interest}

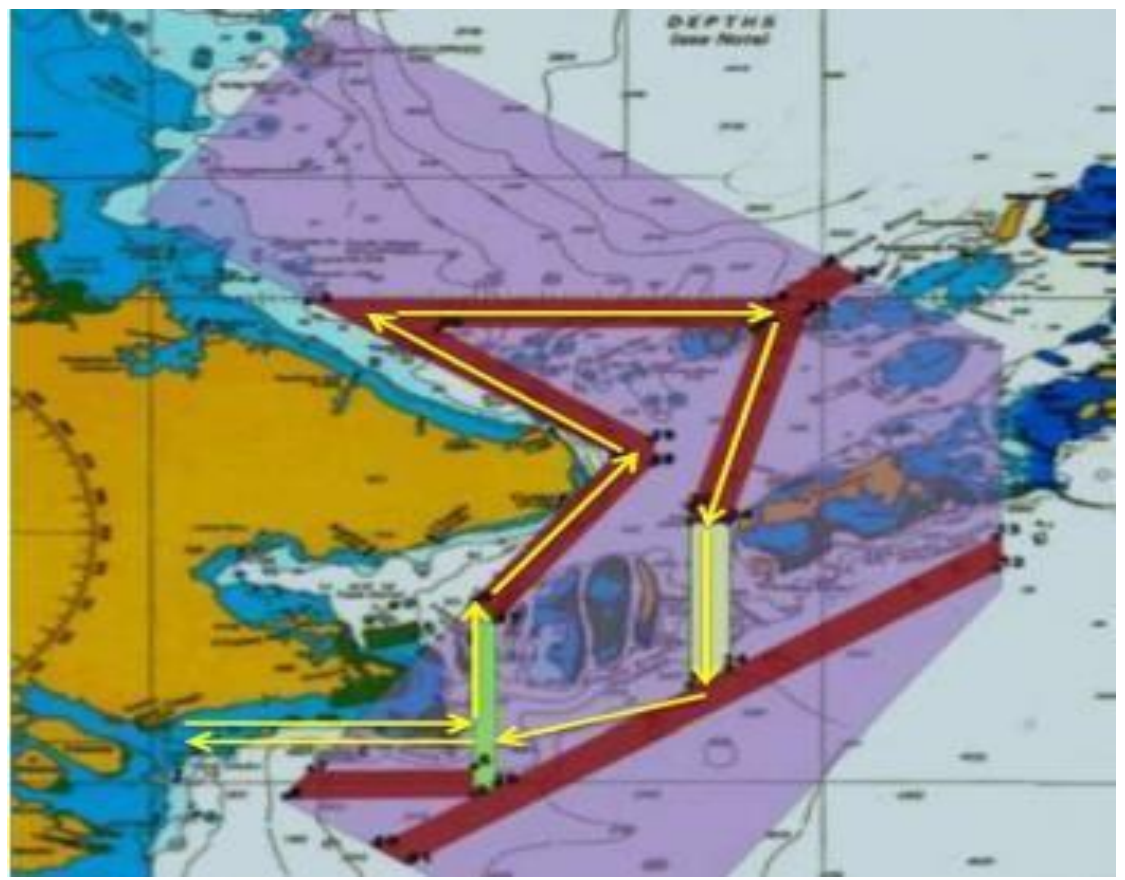

Sumber : (Safety4SEA 2017)

Gambar diatas menunjukkan koridor-koridor yang telah diciptakan oleh ketiga negara sebagai upaya untuk mengurangi kejahatan di lautan. Koridor ini merupakan salah satu beberapa bentuk manuver yang dilakukan oleh Indonesia, Malaysia dan Filipina dalam trilateral maritime patrol. Patroli yang dilakukan ketiga negara kemudian berawal dari pangkalan laut (naval base) yang berada di Tarakan, kemudian ke Borneo Utara untuk memperlihatkan peluncuran coordinated maritime patrol yang telah dilakukan dan untuk meningkatkan keamanan maritime di wilayah perairan Sulu (Tubeza 2017). 
Sehingga dalam hal ini dapat dilihat bahwa variabel maritime border protection tidak hanya berbicara mengenai bagaimana suatu negara mengamankan wilayah yurisdiksi perbatasannya saja tetapi juga harus diimbangi dengan beberapa aktivitas seperti joint operation maupun maritime patrol.

Dalam kasus Laut Sulu penulis melihat bahwa variable ini sangat dapat menjelaskan upaya dan strategi keamanan maritime yang telah dilakukan Indonesia dalam menanggulangi segala bentuk kejahatan di lautnya, termasuk kejahatan pembajakan dan perompakan (maritime piracy). Lebih jauh penulis melihat bahwa indikator-indikator yang telah dijelaskan diatas saling terhubung satu sama lain dimana indikator tersebut penulis rasa merupakan bagian-bagian dari payung besar kerangka kerjasama ketiga negara (Trilateral Cooperation Agreement) yang dilakukan oleh Indonesia, Malaysia dan Filipina sebagai bentuk upaya proteksi dan penanganan terhadap kasus kejahatan di Laut Sulu. Bain maritime patrol maupun joint operation yang sebenarnya juga belum dilaksanakan dilihat mampu untuk melindungi wilayah-wilayah terluar yurisdiksi masing-masing negara. Dalam hal ini adanya patroli terkoordinasi di lautan yang dilakukan oleh masing-masing negara penulis rasa dapat menjadi komponen utama untuk mengatasi permasalahan dan kejahatan di Laut Sulu.

\section{Aktivitas Militer di Wilayah Laut Sulu}

Dalam variable military activities at sea menjelaskan bagaimana aktivitas militer berperan penting dalam bidang pertahanan dan keamanan. Indonesia dalam hal ini menekankan pada penguatan pertahanan di laut dan udara (Taylor Routledge \& Francis Group n.d.). Pendekatan ini dalam tulisan Chris Rahman melihat pada aktivitas militer di lautan melihat keamanan secara tradisional seperti dalam konsep common security. Termasuk penekanan terhadap penggunaan senjata (arms control), khususnya dalam operasi- operasi yang beragam. Aktivitas militer di lautan umumnya didominasi oleh aktivitas yang dilakukan angkatan laut. Lebih lanjut Chris Rahman menjelaskan bahwa tidak semua aktivitas militer harus selalu berkaitan dengan arms control, penggunaan senjata secara gamblang. Arms control disini juga dapat digunakan sebagai media advokasi untuk mempromosikan the operational arms control aspects of naval/ maritime confidence building measures melalui tiga kategori (Rahman 2009):

(1) Declaratory, menerangkan mengenai prinsip utama, termasuk kesepakatan batas wilayah, intensi negara terhadap non agresi dan non nuklir status serta aksesi dalam the Law of the Sea Convention

(2) Transparency, diukur melalui pertukaran informasi pada communications measures dengan mendirikan jaringan dan prosedur selama krisis misalnya; notification measures yang menyediakan pemberitahuan terkait latihan gabungan militer atau unusual deployment; observation/inspection measures, dengan secara sukarela memberikan informasi mengenai pelatihan kemiliteran maupun fasilitas persenjataan angkatan laut suatu negara.

(3) Constraint, yang dapat dicegah melalui risk reduction measures melalui perjanjian atau kesepakatan antar angkatan (laut) bersenjata negara-negara untuk mencegah konfrontasi yang tidak diinginkan.

Hal ini kemudian tercermin dalam upaya-upaya operasi militer yang dilakukan TNIAL sebagai upaya yang ditujukan untuk mengantisipasi dan menanggulangi hal tersebut. Operasi Pembebasan Sandera (Operasi Basra) Tug Boat Brahma 12 di Tawi-Tawi, Filipina dan Tug Boat Henry EX di Banjarmasin yang berlayar dari Cebu ke Banjarmasin merupakan beberapa diantaranya. Berikut merupakan detail yang dilakukan oleh TNI-AL sebagai upaya dalam mengantisipasi insiden pembajakan yang dilakukan oleh Kelompok Abu Sayyaf. 
TB BRAHMA-12 merupakan kapal jenis tug boat (kapal tunda) yang berasal dari Indonesia. Kapal ini membawa muatan baja yang melewati Perairan Sulu untuk diekspor ke Filipina. Kapal ini memiliki 10 anak buah kapal (ABK) yang merupakan Warga Negara Indonesia. Kapal berbendera Indonesia ini ditemukan pada tanggal 26 Maret 2016 di perairan Languyan, Tawi-Tawi, Mindanao Selatan. Diduga ada insiden pembajakan yang dilakukan oleh Kelompok Abu Sayyaf karena pada tanggal 27 Maret 2016 kapal tersebut dalam keadaan kosong dan di dalam Tug Boat masih penuh berisi bahan makanan yang diduga sebagai bekal perjalanan selama pelayaran. Pada saat ini belum diketahui motif dan keberadaan seluruh ABK yang berada di kapal tersebut. Pada 28 Maret 2016 didapatkan informasi bahwa Kelompok Abu Sayyaf meminta tebusan sebesar 10 Milyar peso untuk 10 orang WNI ABK dari TB BRAHMA 12 (Yusup 2018).

Mengetahui hal tersebut pengerahan alutsista yang dilakukan TNI- AL sebagai upaya pembebasan sandera antara lain dengan menggunakan KRI SBY-591 melakukan Operasi Komodo Jaya-16 (DWD TRK 0331.0800) dengan mengerahkan personel sebanyak 153 orang. Seluruh unsur yang terlibat operasi pembebasan sandera kemudian berada di Tarakan pada 4 April 2016, pemerintah bekerja sama dengan Malaysia dan Filipina mengambil langkah setelah adanya kasus penculikan ABK WNI tersebut dan penculikan pada 1 April terhadap empat pelaut di Sarawak di Pulau Ligitan di sepanjang perbatasan Malaysia-Filipina di Laut Sulawesi.

Pemerintah kemudian mengirim tiga batalyon untuk memperkuat pengawasan di perairan Sabah. Kemudian menempatkan joint task force untuk lebih memperkuat pengawasan di wilayah tersebut. Selain hal tersebut, pemerintah menerapkan pendekatan "wait and see" serta upaya negosiasi untuk memantau situasi kemajuan lebih lanjut (Yusup 2018). Pemerintah kemudian terus melakukan upaya komunikasi dan koordinasi dengan pemerintah Filipina terkait pembebasan sandera tersebut hingga pada tanggal 6 April 2016 10 ABK Indonesia yang disandera berhasil diselamatkan.

Kejadian serupa juga sempat dialami oleh TB Henry yang merupakan kapal berbendera Indonesia yang dibajak dalam perjalanan dari Cebu ke Banjarmasin oleh ASG. Sebanyak 10 kru kapal WNI diculik dengan motif untuk mencari dana kampanye menjelang pemilu Mei 2016. Sehingga dalam hal ini militer Indonesia bekerja sama dengan angkatan laut Filipina dalam upaya untuk mengatasi keadaan tersebut. Operasi pembebasan sandera mulai dilakukan sejak pihak Indonesia menerima informasi dari Filipina pada 19 April 2016 terkait kejadian tersebut. Kemudian operasi terus dilakukan hingga 15 Mei 2016 sampai semua kru kapal selamat dan tidak ada korban.

Dalam hal ini upaya pembebasan sandera yang dilakukan oleh TNI AL dilakukan melalui operasi-operasi antara Indonesia-Filipina dengan melibatkan KRI (Kapal Perang RI) dan BRP (Kapal Perang Filipina). Upaya yang dilakukan dalam hal ini mencakup pendekatan yang dikatakan oleh Chris Rahman terkait the operational arms control aspects of naval/maritime confidence building measures, dimana dalam tahap (1) Declaratory, Indonesia dan Filipina mengetahui batas yurisdiksi maritime masing-masing negara sehingga operasi militer yang dilakukan adalah di wilayahnya masing-masing; (2) Transparency, hal tersebut kemudian dikoordinasikan melalui pertukaran informasi antar keduanya melalui maritime command center dalam rangka upaya pembebasan sandera; (3) Constraint, upaya-upaya tersebut kemudian minim melibatkan penggunaan arms control dan lebih mengedepankan negosiasi dalam operasinya.

Lebih lanjut dalam melihat bagaimana aktivitas militer yang telah dilakukan suatu negara dalam upaya penanggulangan kejahatan di lautan maka perlu juga untuk melihat adakah joint force employment yang dilakukan oleh negara tersebut. Pelaksanaan joint force employment atau latihan gabungan militer menurut Laksma Yusup sejauh ini belum pernah 
dilaksanakan untuk menanggulangi kejahatan di Laut Sulu. Laksma Yusup selaku asisten operasi TNI AL mengatakan bahwa latihan gabungan dirasa tidak perlu dilakukan dalam mengantisipasi kejahatan di Laut Sulu mengingat perkembangan penuntasan masalah kejahatan sudah cukup terkendali dengan baik. Sementara ini upaya yang dilakukan oleh Indonesia masih mengembangkan dan melakukan patroli terkoordinasi yang dapat dikatakan cukup efisien dalam mengurangi penculikan dan kejahatan yang terjadi di Laut Sulu seperti yang dikatakan oleh Laksma Yusup:

"Ya boleh dikatakan 2017 hampir tidak ada. 2018 kemarin itu baru sekali kapal berbendera Malaysia. Artinya sudah turun drastis, boleh dikatakan hampir tidak ada. Karena dari pelaksanaan patroli yang dilaksanakan terusmenerus di wilayahnya masing-masing ketiga negara itu oleh $A L$ ketiga negara masing-masing." (Yusup 2018)

Sehingga dalam hal ini patroli terkoordinasi yang dilakukan ketiga negara di wilayah yurisdiksi perairan masing-masing dapat dengan signifikan mengurangi jumlah kejadian piracy yang terjadi dari tahun 2016 ke 2017. Pelaksanaan patroli terkoordinasi ini dilakukan dalam waktu yang berbeda, tidak seperti joint patrol yang dilakukan dalam waktu bersamaan dan membutuhkan biaya yang besar karena ketiga negara mengeluarkan alutsistanya seperti kapal perang disaat bersamaan dan melaksanakan patroli terus-terusan di perairan tersebut. Hal ini masih belum dapat dilakukan karena adanya keterbatasan anggaran dsb. Maka upaya yang ditempuh pemerintah, dalam hal ini TNI-AL sebagai pelaksana operasi adalah melaksanakan patroli di wilayah perairan masing-masing negara, melakukan informasi sharing serta melakukan operasi harian yang dilaksanakan secara periodik untuk berjaga-jaga akan kemungkinan terjadinya kasus kejahatan yang tidak diinginkan.

Penggunaan senjata (arms control) dalam upaya menanggulangi kejahatan pembajakan dan penculikan tidak dilakukan secara langsung seperti dalam upaya pembebasan sandera dari kasus pembajakan di Somalia, melainkan penggunaan senjata yang dilakukan di perairan Sulu hanya sebatas untuk menjaga dan melindungi keamanan laut di wilayah perairan ini. Seperti yang dikatakan oleh Laksma Yusup bahwa penggunaan senjata secara langsung dilakukan karena patroli yang dilakukan menggunakan kapal perang, namun untuk kasus pembebasan sandera yang telah diculik oleh ASG tidak sampai menggunakan senjata dalam upaya pembebasannya (Yusup 2018). Lebih lanjut beliau mengatakan bahwa upaya yang dilakukan oleh pemerintah lebih banyak dilakukan melalui pendekatan negosiasi. Dalam hal ini dijelaskan bahwa negosiasi yang dilakukan juga termasuk didalamnya adalah melakukan patroli secara ketat oleh negara- negara sehingga para pelaku kejahatan tidak memiliki celah untuk melaksanakan aksinya. Hal ini dikatakan beliau mengurangi banyak kejadian yang terjadi di perairan Sulu.

Patroli terkoordinasi ini juga dapat dikatakan sangat efektif dalam mengurangi ancaman mengingat dalam forum ADMM (ASEAN Defence Ministerial Meeting) yang dihadiri oleh 10 negara serta termasuk tambahan ADMM-Plus itu plus 8 negara lagi, disampaikan oleh Menteri Pertahanan Indonesia bahwa telah dinyatakan trilateral untuk aspek operasi laut keberhasilannya baik karena dapat menurunkan drastis jumlah piracy dan robbery di perairan ini. Kapabilitas kekuatan AL ketiga negara juga sebenarnya dapat dibilang cukup besar apabila negara-negara ingin untuk melibatkan hal tersebut dalam operasinya. Namun hal tersebut tidak dilakukan karena dirasa belum perlu untuk itu, mengingat ancaman ASG di Laut Sulu yang masih bias di tackle dengan berbagai patroli yang dilakukan dan upaya kerjasama yang epik antar ketiga negara. Namun hal tersebut tidak menutup kemungkinan bahwa suatu saat ketiga negara bisa saja melakukan arms control untuk menanggulangi ancaman tersebut. Seperti pernyataan yang diutarakan oleh Kolonel Kav Oktaheroe Ramsi bahwa arms control hm kalau kita punya marshall law yang menjanjikan kapal-kapal itu dijaga oleh militer. 
Tapi kita tidak melakukan itu, kita lebih memilih bahwa kapal-kapal itu kita jaga tetapi tidak memilih kapal- kapal itu dipersenjatai (Ramsi 2018; Yusup 2018). Lebih lanjut kemudian Laksma Yusup juga menjelaskan bahwa upaya yang dilakukan sampai saat ini masih pada batas dan pendekatan negosiasi. Serta pengadaan patroli yang sangat ketat juga telah dirasa cukup untuk membuat aktor dan pelaku kejahatan berpikir ulang untuk melakukan aksinya.

Tabel 1. Kapabilitas Angkatan Laut Indonesia, Malaysia dan Filipina

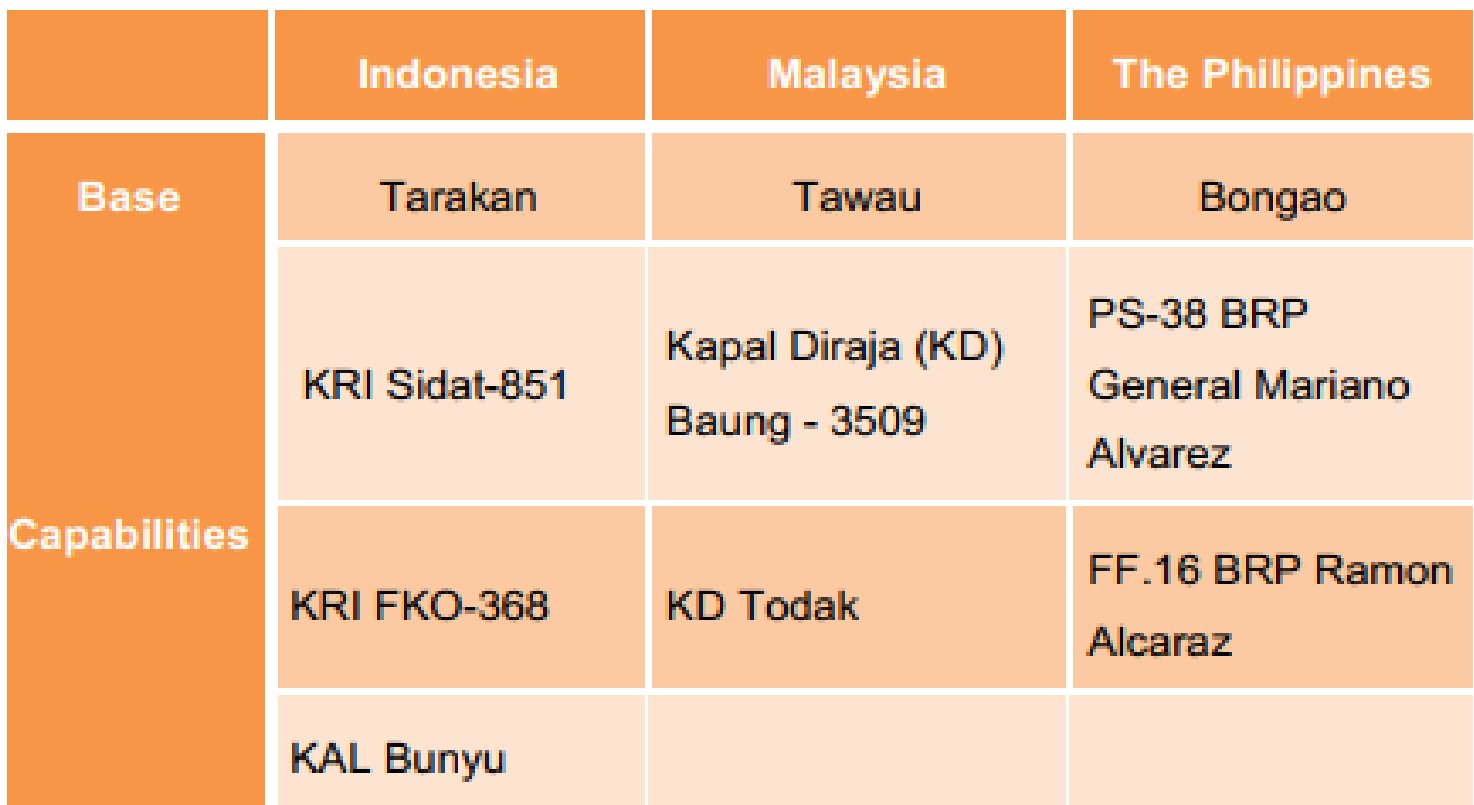

Sumber: (Kemlu n.d.)

Sebagai upaya untuk menjaga kepentingan nasional ketiga negara di dalam konteks keamanan maritime di Laut Sulu, tabel diatas kemudian menentukan kapabilitas militer yang dimiliki oleh Indonesia, Malaysia dan Filipina. Namun walaupun ketiga negara masingmasing telah memiliki kapal perang untuk mendukung operasinya, tetapi air forces capabilities juga masih tetap dibutuhkan untuk membantu pelaksanaan Trilateral Maritime patrol yang diadakan oleh ketiga negara tersebut (Ramsi 2018; Yusup 2018). Dalam hal ini dapat dilihat bahwa selain aspek non tradisional seperti beberapa variabel yang telah dibedah oleh penulis diatas, variable tradisional seperti aktivitas militer di lautan masih menjadi komponen utama dalam upaya penyelamatan dan pembebasan sandera. Upaya militer dalam hal ini juga menjadi komponen penting yang dilakukan oleh Indonesia dalam upaya menanggulangi kejahatan maritime piracy di Laut Sulu.

Berbagai latihan militer, upaya latihan gabungan maupun operasi penyelamatan ABK yang disandera menggunakan KRI (yang sudah barang pasti menyediakan senjata disana, namun tidak dipergunakan) dapat dilihat sebagai upaya yang cukup baik dalam mendukung TCA terlaksana dengan baik di Laut Sulu-Sulawesi. Sehingga dampaknya secara lebih jelas terasa bahwa terjadi pengurangan signifikan jumlah kejahatan maritime piracy yang terjadi dari tahun 2016 ke 2017.

\section{Sistem Regulasi Keamanan pada Moda Transportasi Laut}

Regulasi terhadap transportasi maritime internasional telah menjadi konsen semenjak terjadinya insiden 9/11 yang kemudian dianggap sebagai suatu isu keamanan dan perlu diatur oleh the International Maritime Organization (IMO). Dalam hal ini regulasi dalam shipping (perkapalan) serta transportasi kelautan penting kemudian untuk memperketat regulasi terhadap hal ini agar terhindar dari kemungkinan adanya ancaman teroris, mengingat bahwa 
transportasi kelautan sangat rentan terhadap ancaman. Maka dalam hal ini regulasi yang ditetapkan oleh IMO terhadap maritime transportation system dilakukan untuk mencegah adanya dominasi dan eksploitasi terhadap hal ini oleh kelompok teroris, perompak, maupun ancaman-ancaman lain yang mungkin terjadi pada transportasi laut (kapal) di lautan di seluruh dunia. IMO dalam hal ini memiliki kewenangan untuk mengatur dan legitimasi sebagai wadah negara-negara untuk mengamankan wilayah kelautannya melalui regulasi serta kesepakatankesepakatan yang ada (Rahman 2009).

International Maritime Organization (IMO) adalah suatu badan khusus PBB yang memiliki tanggung jawab dalam keselamatan dan keamanan aktivitas pelayaran dan pencegahan polusi di laut oleh kapal. IMO secara teknis memiliki tugas untuk mengembangkan dan mengadopsi peraturan baru dan pemutakhiran legislasi yang ada melalui pertemuan yang dihadiri oleh ahli maritime dari negara anggota, organisasi antar pemerintah dan non pemerintah, dsb (Kemlu n.d.). IMO dalam hal ini memiliki mandate untuk membuat jalur perdagangan dan aktivitas perdagangan yang melewati lautan dapat terjamin keamanannya (IMO n.d.).

MO dalam hal ini juga mengatur mengenai standarisasi penggunaan alat dan juga keselamatan pelayaran sehingga setiap negara memiliki kewajiban untuk menjaga keamanan dan keselamatan navigasi di negaranya. Sejalan dengan agenda Nawa Cita Presiden Joko Widodo untuk mewujudkan Indonesia sebagai negara maritime, salah satu bentuk upaya yang dilakukan oleh Indonesia adalah secara aktif berpartisipasi dalam IMO yang merupakan upaya penguatan kebijakan politik luar negeri yang dilandasi pada kepentingan nasional dan jati diri bangsa sebagai negara maritime.

Hasil pertemuan komite dan sub-komite IMO kemudian menghasilkan suatu konvensi internasional yang komprehensif dengan berbagai rekomendasi yang mengatur berbagai fase dalam bidang pelayaran internasional seperti (1) Kegiatan yang ditujukan bagi pencegahan kecelakaan, termasuk di dalamnya standar rancangan kapal, konstruksi kelengkapan, kegiatan operasional dan ketenagakerjaan berdasarkan perjanjian internasional; (2) Kegiatan yang perlu untuk mendata adanya kecelakaan, termasuk didalamnya terkait regulasi dalam komunikasi keadaan darurat dan keselamatan, serta (3) Adanya konvensikonvensi yang menimbulkan rezim kompensasi dan pertanggungjawaban (IMO n.d.).

Indonesia dalam hal ini juga telah menjadi anggota aktif dalam berbagai kegiatan IMO sejak tahun 1961. Salah satunya dengan menunjukkan peran aktif dengan mempromosikan pengembangan kerjasama internasional dalam bidang keselamatan dan keamanan pelayaran, termasuk dalam bidang perlindungan lingkungan laut. Indonesia telah menjadi anggota Dewan IMO pertama kali pada tahun 1973. Kemudian berlanjut pada dua periode keanggotaan selanjutnya pada 1975 dan 1977. Indonesia sempat gagal menjadi dewan anggota IMO pada tahun 1979 dan 1981, namun kembali terpilih pada Sidang Assembly ke 13 pada tahun 1983 sampai saat ini (IMO n.d.). Indonesia dalam hal ini juga telah melaksanakan kerjasama dengan IMO dalam melaksanakan tanggung jawab untuk menjaga keselamatan, keamanan dan perlindungan lingkungan hidup.

Sehingga dalam hal ini penulis melihat bahwa keterlibatan IMO sebagai suatu badan yang meregulasi maritime transportation system sangat berpengaruh terhadap keselamatan kapal yang hendak melintasi perairan luas. Lebih lanjut penulis melihat bahwa regulasi yang telah ditetapkan oleh IMO mengenai keselamatan transportasi kelautan telah ditaati dan dipahami secara jelas oleh Indonesia, dimana hal ini bisa jadi digunakan sebagai upaya untuk mengurangi jumlah signifikansi kejahatan pembajakan oleh ASG di Laut Sulu. Kepatuhan dan keterlibatan Indonesia dalam IMO penulis lihat sebagai bentuk dari sikap antisipasi Indonesia akan kemungkinan kejahatan transnasional yang mungkin akan terjadi di lautan. Hal ini juga dapat dilihat sebagai upaya pencegahan yang dilakukan pemerintah agar ABK 
WNI terhindar dari pembajakan, penculikan dan penyanderaan yang kerap dilakukan oleh ASG di Perairan Sulu.

\section{KESIMPULAN}

Wilayah perairan Laut Sulu merupakan laut yang cukup strategis karena di Laut SuluSulawesi merupakan wilayah ALKI II (archipelagic sea lane) Indonesia yang memanjang dari Selat Lombok-Selat Makassar- Laut Sulu Sulawesi yang dilewati oleh sebagian besar VLCC (kapal tanker) ukuran besar menuju Filipina, Malaysia, China, dsb. Jalur perdagangan melalui laut yang ramai ini kemudian menyebabkan munculnya ancaman di wilayah perairan ini termasuk di dalamnya ancaman pembajakan dan juga penculikan awak kapal (maritime piracy). Strategi keamanan maritime yang dilakukan oleh pemerintah untuk menanggulangi hal ini mendapatkan pandangan yang luas melalui konsep maritime security yang dijelaskan oleh Chris Rahman. Konsep ini melihat dalam kacamata yang lebih besar, dimana keamanan tidak melulu hanya berkaitan soal hal-hal yang bersifat tradisional (militer dan penggunaan senjata), melainkan ada hal-hal lain yang bersifat non-tradisional yang mendorong hal tersebut. Dalam pendekatan ini variabel-variabel yang perlu diperhatikan dalam melihat strategi keamanan maritim suatu negara secara utuh dapat dilihat melalui (1) security of the sea itself: conservation and protection; (2) ocean governance;(3) maritime borderprotection; (4) military activities at sea serta (5) security regulation of the transport marine system yang satu sama lain berkesinambungan dan memiliki kaitan yang erat. Dalam menjelaskan bagaimana strategi keamanan maritim yang dilakukan pemerintah Indonesia dalam menanggulangi maritime piracy di Laut Sulu penulis rasa hanya dua dari lima variabel yang benar-benar dapat diimplementasikan dan dilihat sebagai suatu strategi keamanan yang pas untuk mengatasi hal tersebut.

Lebih lanjut dalam menjelaskan strategi keamanan maritime Indonesia penulis melihat bahwa variabel maritime border protection dan military activities at sea merupakan dua variabel yang kemudian cocok dan dapat diaplikasikan. Penulis dalam hal ini melihat bahwa sebuah kerangka kerjasama antar tiga negara yang dilakukan oleh Indonesia, Malaysia dan Filipina dalam bentuk Trilateral Cooperation Agreement. TCA yang kemudian menjadi tolak ukur yang signifikan dalam melihat strategi keamanan maritime yang dilakukan Indonesia. Penanggulangan maritime piracy di Laut Sulu yang merupakan perairan yang berbatasan dengan tiga negara kemudian mengharuskan Indonesia untuk melakukan kerjasama kooperatif dengan dua negara lain dalam menanggulangi maritime piracy di Laut Sulu. Kesepakatan ini tidak hanya berbicara dari segi keamanan saja, melainkan juga menyinggung soal pentingnya pengembangan kawasan perbatasan serta pembangunan di wilayah tersebut untuk mengurangi kerawanan di wilayah perbatasan Indonesia yang dituangkan dalam kebijakan-kebijakan Indonesia terhadap hal tersebut.

Sehingga dalam hal ini melalui berbagai variabel yang telah dijelaskan oleh penulis, keamanan maritime yang dilakukan Indonesia di wilayah perbatasan dengan melakukan kerjasama dengan Malaysia dan Filipina juga dapat dikatakan berhasil. Dimana patroli terkoordinasi yang dilakukan oleh tiga negara terbukti dapat mengurangi jumlah kejadian kejahatan maritime piracy yang terjadi di Laut Sulu. Namun selain patroli terkoordinasi yang merupakan bagian dari TCA yang dapat dikatakan berhasil dalam mengurangi kejahatan di Laut Sulu, variable lain yakni aktivitas militer penulis rasa juga merupakan penentu strategi keamanan maritime yang telah dilakukan Indonesia dalam menanggulangi maritime piracy. Mengingat bahwa isu keamanan yang penulis angkat masih sangat berkaitan erat dengan aspek tradisional dan kemiliteran dalam upaya penanggulangannya. Akhir kata, walaupun kerangka yang digambarkan Chris Rahman dalam menjelaskan maritime security sangat besar dan general, mencakup aspek tradisional dan non tradisional serta tidak semua variabel berhasil 
diaplikasikan dalam studi kasus yang penulis angkat, penulis tetap beranggapan bahwa seluruh variabel saling berkaitan dan memberikan dampak yang signifikan bagi terciptanya keamanan maritime yang stabil di Laut Sulu.

\section{DAFTAR PUSTAKA}

Ambari, M. n.d. "Bentang Laut Sulu Sulawesi Jantung Segitiga Karang Dunia."

Bagus, I. Gusti Dhama Agastia; A. .. Banyu Perwita. 2016. Maritime Security in the Indo-Pacific. Yogyakarta: Graha Ilmu.

BBC Indonesia. 2016. "Dua Kapal Indonesia Dibajak Di Filipina, 10 WNI Disandera." BBC Indonesia, March 25.

BBC Indonesia. 2017. "Laut Sulu Merupakan Perairan Paling Berbahaya Di Dunia." April 1. BPK RI. 1996. Undang-Undang (UU) Tentang Perairan Indonesia. Indonesia: LN. 1996, LL SETNEG : 19 HLM.

Buerger, Christian. 2015. "What Is Maritime Security?” Forthcomin in Marine Policy.

Burhanudin. n.d. "Strategi Keamanan Maritim Indonesia Di Laut Sulu. Interview." 2018.

Conway, James T; et al. 2008. A Cooperative Strategy for 21st Century Seapower. Naval War College Review: Winter.

Coral Triangle Initiative. n.d. "Prakarsa Segitiga Karang Untuk Terumbu Karang, Perikanan, Dan Ketahanan Pangan: Model Umum Bentang Laut Dan Kerangka Regional Bentang Laut Prioritas."

Retrieved

(http://www.coraltriangleinitiative.org/sites/default/files/resources/Seascap

es

Document_bahasa_version 1.pdf).

DURSIN, KANIS. 2016. "Ancaman Abu Sayyaf: Mengapa Laut Sulu Penting Untuk Indonesia?” Rappler. Retrieved (https://www.rappler.com/world/mengapa-laut-sulupenting-untuk-indonesia).

Febrica, Senia. 2017. Indonesian Immigration AgencyMaritime Security and Indonesia: Cooperation, Interest and Strategies, Dalam Senia Febrica. New York: Routledge.

GMA News Online. n.d. "Abu Sayyaf Kidnappings, Bombings and Other Attacks."

Gumilang, Prima. 2016. "Pembajakan Di Filipina, Indonesia Taruh Tentara Dalam Kapal." July 2.

ICC IMB. 2017. Piracy and Armed Robbery Against Ships. Report for the Period 1 January - 31 Desember 2017. London.

IMO. "M.d. "Maritime Security and Piracy." Retrieved (http://www.imo.org/en/OurWork/Security/Pages/MaritimeSecurity.aspx).

Johnson, Derek; Valencia, Mark J. 2005. "Introduction: Research on Southeast Asian Piracy." in Piracy in Southeast Asia: Status, Issues, and Responses. IIAS.

Kemenko Kemaritiman. 2017. Kebijakan Kelautan Indonesia Peraturan Presiden. Indonesia.

Kemenko Kemaritiman. n.d. "Wilayah Perairan, Hak Berdaulat, Kawasan Yurisdiksi, Serta Laut Lepas Dan Kawasan Dasar Laut Internasional." in Buku pedoman Kemenko Kemaritiman RI tentang Kebijakan Kelautan Indonesia.

Kementerian Kelautan dan Perikanan RI. 2017. "Indonesia Menjadi Ketua Kelompok Kerja Teknis Napoleon Wrasse Di Wilayah Sulu-Sulawesi." Retrieved (http://kkji.kp3k.kkp.go.id/index.php/en/beritabaru/228-indonesia-ketua- pokja-sulusulawesi).

Kemlu. n.d. "Diplomasi Maritim: Upaya Mendukung Keamanan Maritim Di Kawasan.” P3K Multilateral Kemlu. Retrieved (https://www.facebook.com/P3KMultilateral/posts/?ref=page_internal).

Kemlu. n.d. "KBRI Indonesia Di London-Konsul Kehormatan RI Di Irlandia." Retrieved (https://www.kemlu.go.id/london/Pages/IMO.aspx). 
Malaysia Kini. 2017. "We Were Treated like Slaves, Says Abu Sayaaf Kidnap Victim." March 28.

Mudric, Miso. 2016. "Maritime Security: Editorial Note." CIRR Jurnal Online Edition 75.

OBP. 2017. "Piracy and Robbery against Ships in Asia 2016." Retrieved (http://oceansbeyondpiracy.org/reports/sop/se-asia).

Oceans Beyond Piracy. 2017. "PIRACY AND ARMED ROBBERY AGAINST SHIPS IN ASIA 2017." The State of Maritime Piracy. Retrieved (https://oceansbeyondpiracy.org/reports/sop/se-asia\#humancostse).

Parameswaran, Prashanth. 2017. "Whates With the New Sulu Sea Trilateral Air Patrols?" Retrieved (https://thediplomat.com/2017/10/whats-with-the-new-sulu-sea- trilateral-airpatrols/).

Partogi, Poltak Nainggolan. 2016. "Pembajakan Kapal Dan Penculikan WNI Oleh Kelompok Abu Sayyaf." Majalah Info Singkat Hubungan Internasional 8(19).

Peraturan Pemerintah RI. 2002. Tentang Hak Dan Kewajiban Kapal Dan Pesawat Udara Asing Dalam Melaksanakan Hake Lintas Alur Laut Kepulauan Melalui Alur Laut Kepulauan. Indonesia. Prastyono, Edy. 2005. Keamanan Internasional DanPolitik Luar Negeri Indonesia, Dalam Bantarto Bandoro (Ed), Mencari Desain Baru Politik Luar Negeri Indonesia. Bantarto B. Jakarta: CSIS.

Presidency of the Government. 2013. "National Maritime Security Strategy 2013.” Jurnal Online.

Rahman, Chris. 2009. "Concept of Maritime Security." New Zealand: Centre for Strategic Studies. Ramsi, Kolonel Kav Oktaheroe. 2018. "Strategi Pertahanan Di Laut Sulu Dalam Upaya Menanggulangi Maritime Piracy. Interview."

ReCAAP. 2016. Annual Report Piracy and Armed Robbery Against Ships in Asia 2016.

ReCAAP. 2017. January-December 2017 Report Annual Piracy and Armed Robbery Against Ships in Asia.

Regional Cooperation Agreement on Combating Piracy and Armed Robbery against Ships in Asia Information Sharing Center (ReCAAP). 2017. Annual Report 2016.

Rustam, Ismah. 2017. "Kebijakan Keamanan Maritim Di Perbatasan Indonesia: Kasus Kejahatan Di Laut Sulawesi-Laut Sulu." Jurnal Online Universitas Mataram 14(2).

Safety4SEA. 2017. "New Maritime Transit Corridors in Effect." Safety4SEA. Retrieved (https://safety4sea.com/new-maritime-transit-corridors-in-

effect/?_cf_chl_jschl_tk_=b2c98413557df49777c54ca649519dd33b4d2bfd-

1621682046-0-AXNPdOdNzygTn199zs8FUyucUouOGe-

yjwvPv75Gzsq8rHUptrl43zmwPYJOa66ttWYmydmwhT_AMnXpUP9p9KOmDX7_57gd q91vOxW6JmV4sGvomuzl1fFyOXLOcnox5T_WCYV0ZWKaXuLU5izp_CBl7q1tWhNu pPW9DSeiLooWRB93dDXF2QOcwbkUvY6y89D1SYqMvAg7xIeIgRRBbo5_MWC-

HpMzlURsbUozgRWzIXBtiuIHC6kIln_rAQUHbUDHCECASk09cRxnjTF3g5GFnlqJEa 16UDG6hc3cX112sh8UE28D3BChIfDrHR_tmVq4KUHhC93FbGZJ0UJhsZA5z0R8mTs M9VttdCmzDQiAneEmVoeyJsGVwuNBAsmWccbdGpm9jQDj18Fv0WyujugdyS1det6ct P-Av2G0gJ8-fCyv7ycm8P8-r6sDusHj9Q).

Stable Seas. 2019. "Stable Seas: Sulu and Celebes Seas." Retrieved (https://www.stableseas.org/post/stable-seas-sulu-and-celebes-seas).

Storey, Ian. 2016. "Addressing the Persistent Problem of Piracy and Sea Robbery in Southeast Asia." Research at ISE AS-Yosuf Ishak Institute (30).

Taylor Routledge \& Francis Group. n.d. “The Military Balance Chapter Six: Asia." Journal of University of Colorado at Boulder Libraries.

Tubeza, Philip C. 2017. "Indonesia, Malaysia, Philippines Launch Naval Patrols." Inquirer, June 19.

UNODC. 2010. TOCTA Report 2010 Maritime Piracy. 
Wallace, Cath. n.d. "The Security of the Marine Environment, Dalam Chris Rahman, Concepts of Maritime Security: A Strategic Perspective on Alternative Visions for Good Order and Security at Sea, with Policy Implications for New Zealand."

Wee, Vincent. 2017. "Indonesia, Malaysia and the Philippines Launch Joint Patrols in Sulu Sea amid Terror Threat." Seatrade Maritime News, June 20.

Wenny Ikhtiari, Richarunia. 2011. . “. Strategi Keamanan Maritim Indonesia Dalam Menanggulangi Ancaman Non-Traditional Security, Studi Kasus: Illegal Fishing Periode Tahun 2005-2010." Tesis Universitas Indonesia.

Winarno, Budi. 2008. Isu-Isu Keamanan Strategis Dalam Kawasan ASEAN. Jakarta: P2P-LIPI. Yusup. 2018. “Operasi Penanggulangan Maritime Piracy Di Laut Sulu. Interview.” 